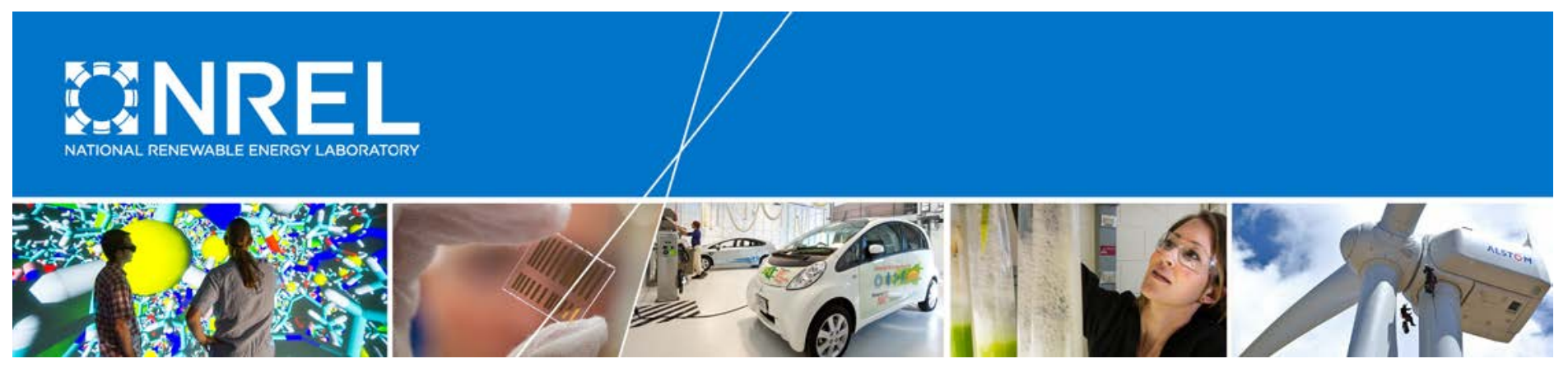

\title{
Mexico's Geothermal Market Assessment Report
}

Francisco Flores-Espino

National Renewable Energy Laboratory

Sarah Booth

Booth Clean Energy LLC

Andrew Graves

U.S. Department of Energy

NREL is a national laboratory of the U.S. Department of Energy Office of Energy Efficiency \& Renewable Energy Operated by the Alliance for Sustainable Energy, LLC

This report is available at no cost from the National Renewable Energy Laboratory (NREL) at www.nrel.gov/publications.

Technical Report

NREL/TP-6A20-63722

March 2017

Contract No. DE-AC36-08G028308 


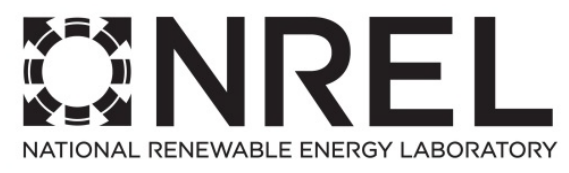

\section{Mexico's Geothermal Market Assessment Report}

Francisco Flores-Espino

National Renewable Energy Laboratory

Sarah Booth

Booth Clean Energy LLC

Andrew Graves

U.S. Department of Energy

Prepared under Task No. IGIN.3600

NREL is a national laboratory of the U.S. Department of Energy Office of Energy Efficiency \& Renewable Energy Operated by the Alliance for Sustainable Energy, LLC

This report is available at no cost from the National Renewable Energy Laboratory (NREL) at www.nrel.gov/publications.

National Renewable Energy Laboratory 15013 Denver West Parkway

Golden, CO 80401

303-275-3000 • www.nrel.gov

\section{Technical Report}

NREL/TP-6A20-63722

March 2017

Contract No. DE-AC36-08G028308 


\section{NOTICE}

This report was prepared as an account of work sponsored by an agency of the United States government. Neither the United States government nor any agency thereof, nor any of their employees, makes any warranty, express or implied, or assumes any legal liability or responsibility for the accuracy, completeness, or usefulness of any information, apparatus, product, or process disclosed, or represents that its use would not infringe privately owned rights. Reference herein to any specific commercial product, process, or service by trade name, trademark, manufacturer, or otherwise does not necessarily constitute or imply its endorsement, recommendation, or favoring by the United States government or any agency thereof. The views and opinions of authors expressed herein do not necessarily state or reflect those of the United States government or any agency thereof.

This report is available at no cost from the National Renewable Energy Laboratory (NREL) at www.nrel.gov/publications.

Available electronically at SciTech Connect http:/www.osti.gov/scitech

Available for a processing fee to U.S. Department of Energy and its contractors, in paper, from:

U.S. Department of Energy

Office of Scientific and Technical Information

P.O. Box 62

Oak Ridge, TN 37831-0062

OSTI http://www.osti.gov

Phone: 865.576.8401

Fax: 865.576.5728

Email: reports@osti.gov

Available for sale to the public, in paper, from:

U.S. Department of Commerce

National Technical Information Service

5301 Shawnee Road

Alexandria, VA 22312

NTIS http://www.ntis.gov

Phone: 800.553 .6847 or 703.605 .6000

Fax: 703.605.6900

Email: orders@ntis.gov 


\section{Acknowledgments}

The authors wish to thank the U.S. Department of Energy (DOE) for sponsorship and guidance on this work, particularly Sheila Moynihan and Mark Reichhardt at the Office of Energy Efficiency and Renewable Energy (EERE). We also would like to thank Kate Young at the National Renewable Energy Laboratory for her review and comments. We also appreciate the critical insights provided by the following individuals, which greatly improved and informed the analysis contained herein:

- Luis Carlos Gutiérrez Negrín, Mexican Geothermal Association

- Dr. Gerardo Hiriart Le Bert, Energías Alternas, Estudios y Proyectos S.A. de C.V. (ENAL)

- Dr. Rosa María Prol Ledezma, Geophysics Institute, National Autonomous University of Mexico (UNAM)

- Enrique Nieto, Inter-American Development Bank

- Raúl Maya González, GEA Alianza para la Exploración Geotérmica S.C.

- Magaly Flores Armenta, Comisión Federal de Electricidad

- Serafín López Pineda, Comisión Federal de Electricidad

- Efraín Villanueva Arcos, Mexico’s Ministry of Energy (SENER)

- Michelle Alejandra Ramirez Bueno, SENER

- David Alejandro Rocha Ruiz, SENER 


\section{List of Acronyms}

BECC

BNEF

BOP

CAGR

CAISO

CEL

CEMIE

CENACE

CFE

CIA

CONACYT

CONAGUA

CRE

CTF

DOE

DOS

EIA

EPC

EPE

ERCOT

ESMAP

ETL

Ex-Im (Bank)

GIF

GoM

GW

GWh

IDB

INERE

IPP

IRENA

ITA

LCOE

MIF

MW

MWh

NADB

NAFTA
Border Environment Cooperation Commission

Bloomberg New Energy Finance

balance of plant

compounded annual growth rate

California Independent System Operator

clean energy certificate(s) (certificados de energías limpias)

Mexican Center for Energy Innovation (Centro

Mexicano de Innovación en Energía)

National Center for Energy Control (Centro

Nacional de Control de Energía)

Federal Electricity Commission (Comisión Federal

de Electricidad)

Central Intelligence Agency

National Council for Science and Technology

(Consejo Nacional para la Ciencia y la Tecnología)

National Water Commission

Energy Regulatory Commission (Comisión

Reguladora de Energía)

Clean Technology Fund

U.S. Department of Energy

U.S. Department of State

environmental impact assessment

engineering, procurement, and construction

El Paso Electric Company

Electric Reliability Council of Texas

Energy Sector Management Assistance Program

Energy Transition Law

Export-Import (Bank)

Geothermal Investment Fund

Government of Mexico

gigawatt

gigawatt-hour

Inter-American Development Bank

National Inventory of Renewable Energy

(Inventario Nacional de Energías Renovables)

independent power producer

International Renewable Energy Agency

U.S. International Trade Administration

levelized cost of energy

Multilateral Investment Fund

megawatt

megawatt-hour

North American Development Bank

North American Free Trade Agreement 


NES
NGDS
O\&M
OPIC
PPA
SEMARNAT
SENER
VAT
U.S. TDA

National Electric System

National Geothermal Data System

operations and maintenance

Overseas Private Investment Corporation

power purchase agreement

Ministry of Environment and Natural Resources

Mexico's Ministry of Energy (Secretaría de

Energía)

value-added tax

U.S. Trade and Development Agency 


\section{Executive Summary}

Recent changes in Mexico's energy sector, combined with the government's ambitious clean energy targets and a variety of other factors, have created favorable conditions for investment in the country's geothermal energy sector. Since 2013, Mexico has enacted comprehensive reforms to open significant components of its energy sector to private investment and accelerate the deployment of new renewable energy generation. These energy reforms present the most significant change to the electricity sector in the country in the last few decades.

Mexico's overall energy demand is expected to grow at an average rate of $3.5 \%$ per year over the next decade, and the government has set an ambitious target of 35\% clean energy generation by 2024 (SENER 2015). Mexico is endowed with significant geothermal energy resources, with estimates ranging from between 5 and 25 gigawatts $(\mathrm{GW})$ of untapped conventional and unconventional resources. Policy measures enacted under the Geothermal Energy Act of 2014 create special incentives for geothermal energy deployment, and the Mexican government anticipates adding 900 megawatts (MW) of new geothermal energy generation by 2029 .

As of March 2017, the government has completed two auctions for long term power purchase agreements (PPAs) for renewable energy production and capacity additions. In total, 74 projects have been selected with an estimated capacity of more than $6.5 \mathrm{GW}$, including a $25-\mathrm{MW}$ geothermal plant (Aymami 2016; PV Tech 2016). The government has also initiated a program for the sale of clean energy certificates (CELs) to track compliance with its mandates for clean and renewable energy. In January 2017, the government released a new energy atlas of potential locations for geothermal and other renewable energy resources across the country. Mexico is also testing a new online platform designed to streamline the permitting process for geothermal energy exploration and development across multiple federal agencies. The state-owned utility, Comisión Federal de Electricidad (CFE), currently has 13 active exploration permits and 5 production licenses, and has expressed an interest in forming partnerships with private companies to survey and develop these resources. In addition, three private companies have secured another five exploration permits and one license. Eighty-one MW of geothermal energy are scheduled to be commissioned between 2017 and 2018. The notice for the third energy auction is scheduled for April 2017, and awarded contracts are scheduled to be announced in October 2017.

This report is intended to help U.S. companies in the geothermal sector understand potential business opportunities created by recent changes in the Mexican energy market and regulatory environment. Currently, there are a variety of avenues for private renewable energy companies to sell electricity into the Mexican market. In addition to securing long term PPAs with the federal government, companies can secure PPAs with local corporate or municipal customers, build turnkey projects for locally active companies, or sell directly into the wholesale electricity market. U.S. companies can also provide a variety of technology products and services for export into the Mexican market. This report will help U.S. companies identify the many public and private sector stakeholders in the United States and Mexico, which can help U.S. companies navigate the new regulatory and permitting environment, build new partnerships, and identify vehicles for financial assistance and risk mitigation. 


\section{Table of Contents}

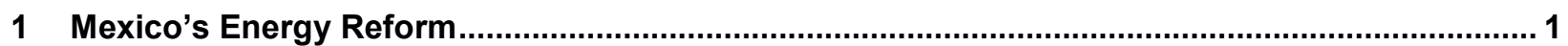

1.1 Constitutional Reforms and Energy Legislation ............................................................ 1

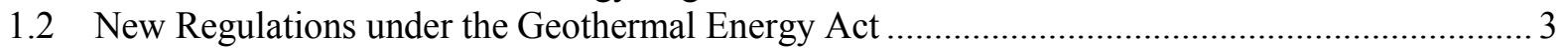

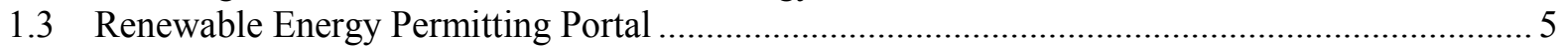

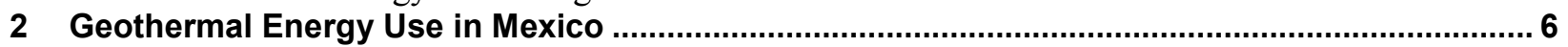

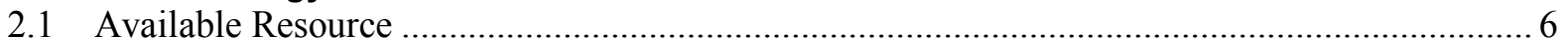

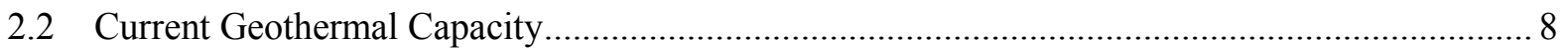

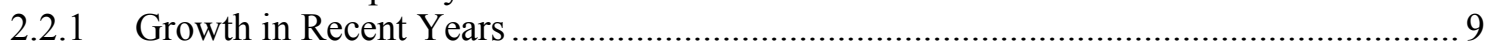

2.2.2 Existing Geothermal Permits and Licenses.......................................................... 9

3 Investment Climate, Opportunities, and Barriers................................................................ 11

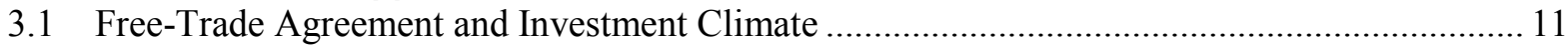

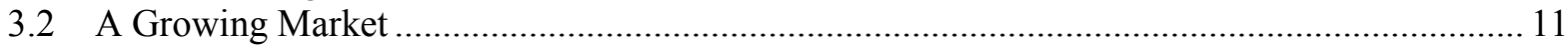

3.3 Entrance Opportunities for Geothermal Developers and Power Producers ................................ 12

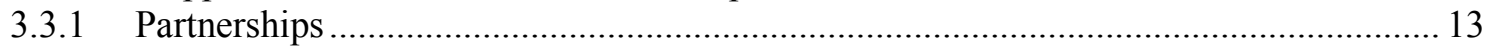

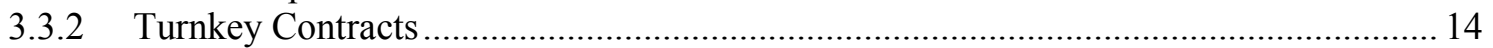

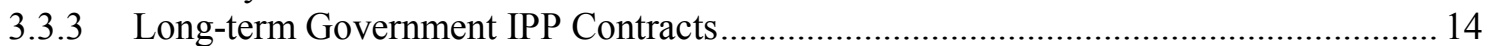

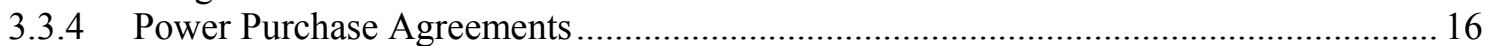

3.3.5 Participation in the Wholesale Market .................................................................... 16

3.4 Entrance Opportunities in the Geothermal Value Chain .......................................................... 16

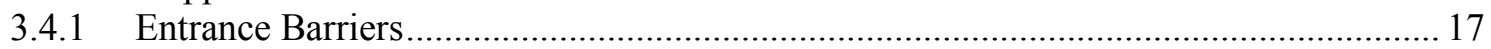

4 Mexican Government Programs, Resources, and Incentives................................................ 20

4.1 Investment Guidance for Foreign Companies....................................................................... 20

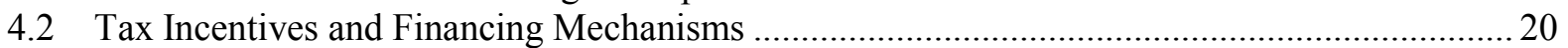

4.3 Exploration Drilling Risk Mitigation Mechanism................................................................ 21

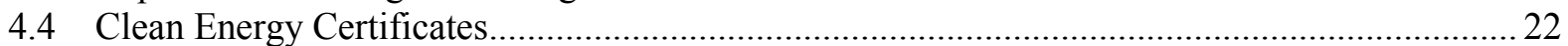

4.5 National Renewable Energy Inventory and Atlas .......................................................... 22

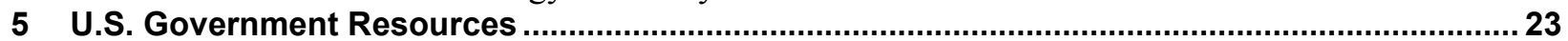

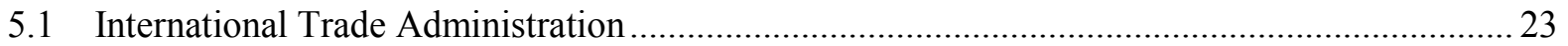

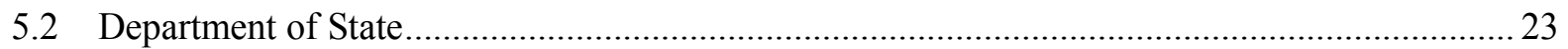

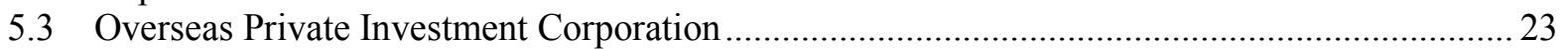

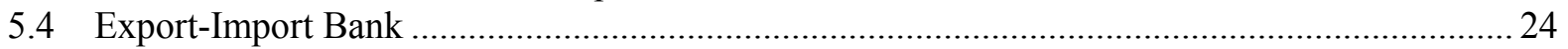

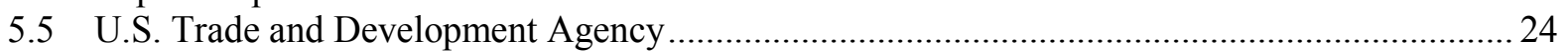

5.6 Border Environment Cooperation Commission and North American Development Bank ........ 25

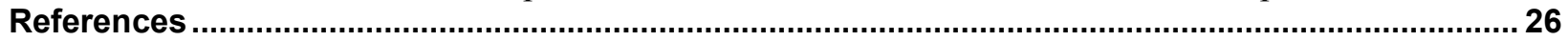

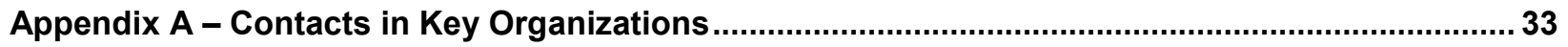

Appendix B - Registration, Permit, and License Minimum Requirements ........................................ 35

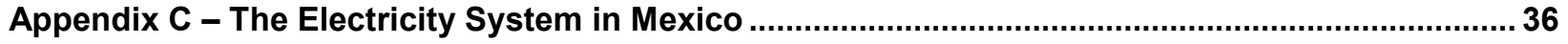




\section{List of Figures}

Figure 1. Timeline for Mexico's energy reform and geothermal market ................................................2

Figure 2. Geothermal development stages as described in the Geothermal Act and relevant regulations.... 4

Figure 3. Estimated underground temperatures in degrees Celsius (SENER 2016c) ............................... 6

Figure 4. Map of 20 locations with high resource potential in Mexico (Hiriart Le Bert 2011).................... 7

Figure 5. Geothermal fields in Mexico (SENER 2016c; Flores-Armenta 2016) .................................... 8

Figure 6. Approximate location of geothermal permits and licenses granted by SENER as of August 2016

(SENER 2016c)....

Figure 7. SENER estimates 895 MW of additional geothermal capacity in the 2016-2030 period.

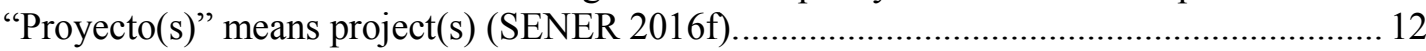

Figure 8. CFE reorganization structure. Nuclear power could be housed under CFE Generation III subsidiary or a separate business unit (Jiménez 2016; SEGOB 2016b; SEGOB 2016a)....... 14

Figure 9. Project and money flow under the drilling mitigation mechanism program ............................ 21

Figure 10. Mexico's international interconnections, 2014 (SENER 2015) …........................................ 36

Figure 11. Mexico's annual electricity trade (SENER 2015) ................................................................. 37

\section{List of Tables}

Table 1. CFE's Geothermal Winning Bid: Plant Size and Annual Revenues (Richter 2016a; CENACE 2016b)

Table 2. Relative Barriers for Foreign Companies to Export Manufactured Goods to the Mexican

Geothermal Market

Table 3. Relative Barriers for Foreign Service Providers to Enter the Mexican Geothermal Market

Table 4. Fuel Sources Used for Electricity Generation in Mexico in 2015 (SENER 2016g) 37 


\section{Mexico's Energy Reform}

\subsection{Constitutional Reforms and Energy Legislation}

In recent years, Mexico has introduced new policies to further the decarbonization of the energy sector and promote renewable energy deployment. Mexico's National Development Plan 20132018 underscores the importance of renewable energy expansion as a strategy to enhance the country's energy diversification and security (GoM 2013). The country's 2012 General Law on Climate Change includes the goal of reducing carbon emissions to $30 \%$ below 2000 levels by 2020 , and $50 \%$ by 2050 . It also mandates that $35 \%$ of the electricity sold in the country must come from non-fossil sources ${ }^{1}$ by 2024, up from 19\% in 2011 (Ley General de Cambio Climático 2012). The Ministry of Energy (SENER) estimates that between 2016 and 2030, 24.3 gigawatts $(\mathrm{GW})$ of renewable energy capacity will be installed in Mexico. Of this total, 894 megawatts (MW) are expected to come from geothermal energy, which would nearly double geothermal deployment in Mexico by 2030 (SENER 2016f).

Mexican law had historically designated electric power generation, transmission, distribution, and sale as public service activities reserved exclusively to the state, which precluded private investment and participation in the electricity market. Congress passed legislative reforms in 1992 to allow private entities to sell power to the Federal Electricity Commission (CFE) for the first time (Ramírez-Camperos, Rodríguez-Padilla, and Guido-Aldana 2013). Reforms to the Constitution approved by the Mexican Congress in 2013 and legislation enacted since 2014 introduced important changes to the way the electrical sector is regulated in Mexico. These reforms have opened the electricity sector more fully to private investment. The goals of the reform include lowering electricity prices to consumers through competition and the participation of the private sector, increasing the share of natural gas and clean technologies in the production of electricity, and accelerating the expansion of transmission infrastructure (GoM, n.d.; PwC 2014). Figure 1 presents a timeline of the reforms.

The most significant changes brought about by the reforms include the following:

- CFE no longer has a monopoly over electricity generation, transmission, and distribution. Domestic and foreign private companies are now allowed to openly participate in the electrical sector as developers and independent power producers. CFE remains a stateowned enterprise. CFE currently operates $84 \%$ of the total capacity installed, including plants owned by CFE and third-party owned plants under long-term contracts with CFE (SENER 2016g, 57). Because this share of electricity generation would give CFE more market power than any other market participant, CFE was divided into six generation subsidiary companies that compete in the market independently with one another. CFE's system operation, distribution, and transmission units have also become independent entities (El Financiero 2016; SENER 2016a).

- The National Center for Energy Control (CENACE), formerly a unit within CFE, became a new decentralized agency in charge of managing the grid and guaranteeing equal access to the wholesale electricity market, equivalent to an independent system operator in the

\footnotetext{
${ }^{1}$ Non-fossil sources include renewable energy, large hydropower, nuclear power, and fossil-fuel plants equipped with carbon capture and sequestration technologies (Fernández Martínez, et al. 2012).
} 
United States. CENACE started operating the Mexican wholesale energy market in February 2016 (Dyer 2016).

- CENACE operates the newly created wholesale day-ahead and real-time markets for electricity. Market participation is open to CFE's generation subsidiaries, independent generators, power marketers, and large consumers. CFE's distribution subsidiary will continue to be the sole supplier of electricity at the retail level for users with a peak demand of less than $1 \mathrm{MW}$. Eventually, the market will also include financial transmission rights (Pavlovic 2015).

- Transmission and distribution networks remain the property of the government. However, they are now operated and maintained by independent subsidiaries of the CFE. Transmission and distribution subsidiaries are not allowed to buy or resell electricity. Private companies will be able to participate in the operation, maintenance, and expansion of the electrical network under contract with CFE's affiliates (Bierzwinksy, Jiménez, and Félix 2014).

- The government has also created several mechanisms to promote investment in renewable energy. These include tax incentives and new financing mechanisms, an exploration risk mitigation insurance product, tradeable clean energy certificates, a renewable energy resource atlas and inventory, and a web portal to simplify permitting processes. See Section 4 for a description of each of these mechanisms and incentives.

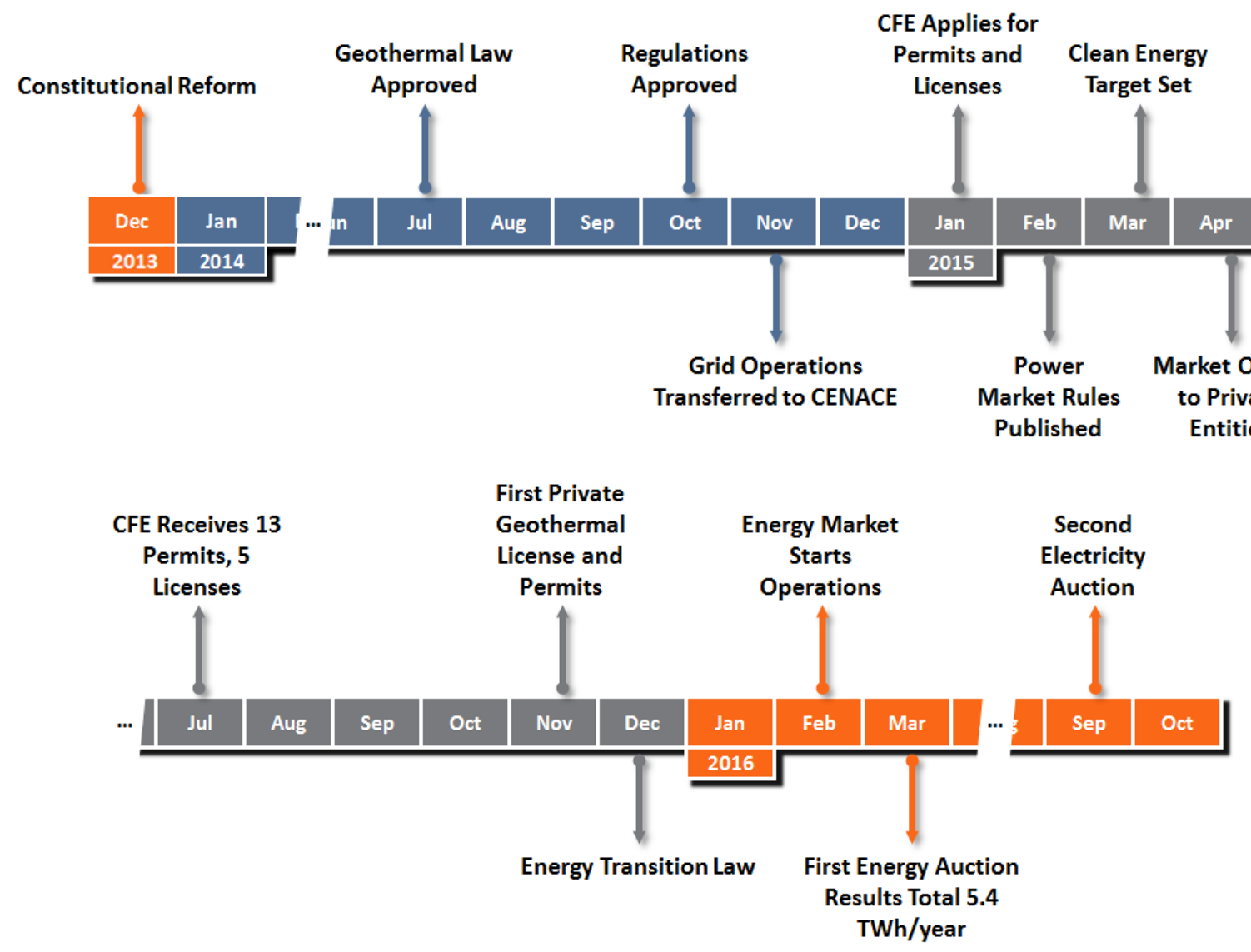

Figure 1. Timeline for Mexico's energy reform and geothermal market 


\subsection{New Regulations under the Geothermal Energy Act}

As part of the package of secondary laws enacted in 2014, the Mexican Congress approved the Geothermal Energy Act. The goals of the Act include providing financial and regulatory certainty to investors and developers and promoting the entry of new participants in the Mexican geothermal sector (Muñozcano Álvarez 2015). The Mexican government did not create technology-specific legislation for any other form of renewable energy.

The Geothermal Act allows private enterprises incorporated under Mexican law, including foreign companies, ${ }^{2}$ to participate in geothermal activities, but not to own geothermal resources. ${ }^{3}$ The Act defines three consecutive stages of geothermal development, each with its own set of requirements (Figure 2). SENER grants geothermal registrations, permits, and licenses, and has the authority to include additional terms and conditions on a case-by-case basis. Companies intending to perform geothermal activities in Mexico must be included in SENER's geothermal activity registry. Permits allow for exploration but do not include the right to exploit a resource. Licenses give holders the right to exploit the geothermal resources but do not confer property rights. Exploration permits and production licenses grant holders exclusive rights to the identified resources, which prevents other entities from exploiting those resources, as long as all permits and licenses remain current (GoM 2014).

\footnotetext{
${ }^{2}$ Mexican law allows foreign companies to incorporate and own companies registered as any of the business entities defined by Mexican law, such as limited liability companies and stock corporations (PwC 2011).

${ }^{3}$ The Mexican Constitution designates the federal government as the sole owner of all minerals and resources beneath the surface, including geothermal waters (BBA 2017).
} 

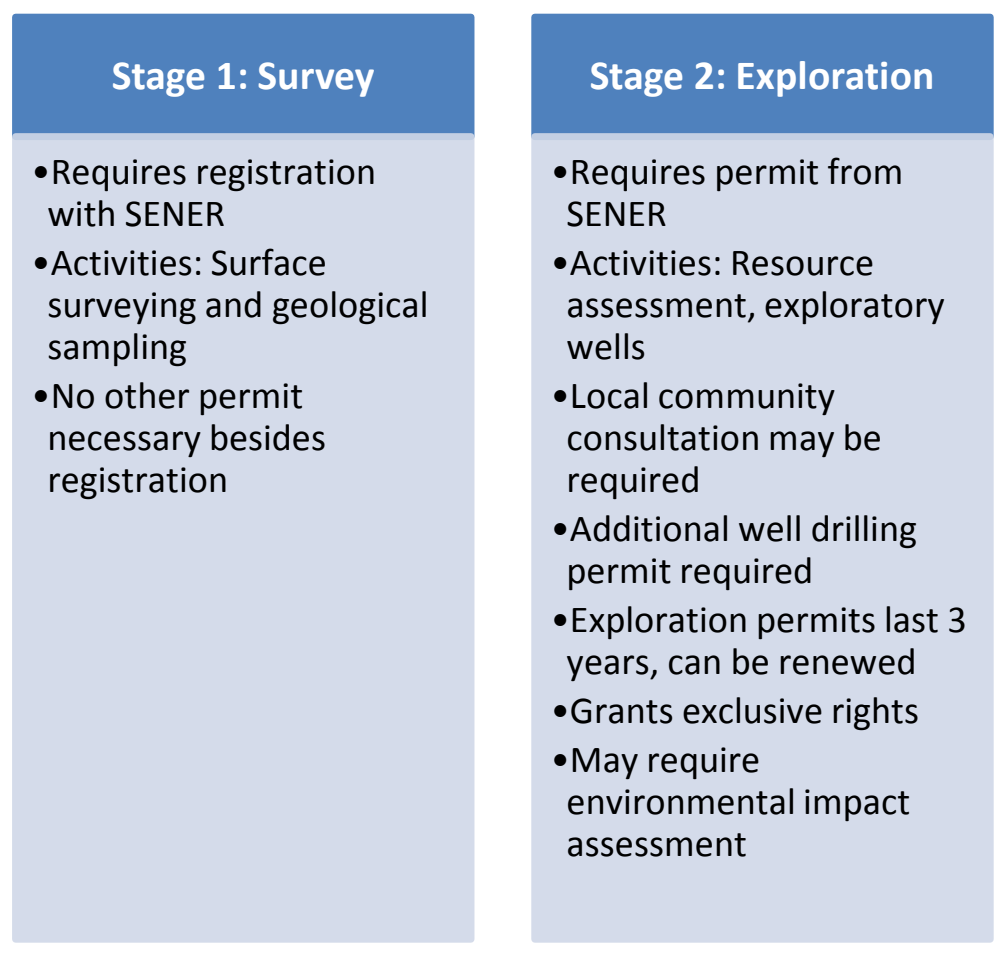

\section{Stage 3: Geothermal \\ Production}

- Requires license from SENER

-Activities: Production well drilling, geothermal resource utilization

- Local community consultation may be required

-Additional water and power production licenses required

- Production licenses valid for 30 years, can be renewed

- Grants exclusive rights

- Requires environmental impact assessment

\section{Figure 2. Geothermal development stages as described in the Geothermal Act and relevant} regulations

Survey activities include surface surveys and geological sampling, including airborne reconnaissance, remote sensing, and geochemical analysis on rock and water samples. Drilling is not permitted at this stage. A registration request must be submitted to SENER for survey activities, which do not require a permit, license, or environmental review. SENER has 10 days to resolve a registration application.

Exploration activities require an exploration permit issued by SENER and a well-drilling permit issued by the National Water Commission (CONAGUA). Activities covered under exploration permits include surface and subsurface resource assessments, exploratory well drilling, and the installation of geothermal exploration equipment. Well-drilling permits are issued for a specific number of wells. Power production is not permitted at this stage. Consultations with relevant stakeholders may be necessary in areas where communal landholders, indigenous peoples, or other protected populations may be affected by geothermal activity. Exploration permits last for 3 years and can be renewed. SENER has a period of 45 days to resolve an exploration permit request. Geothermal exploration activities require authorization from the Ministry of Environment and Natural Resources (SEMARNAT). Exploration activities performed in accordance with the relevant Mexican standard ${ }^{4}$ outside of conservation or forest areas can be authorized by filing a Preventive Inform instead of a full environmental impact assessment (EIA) (GoM 2017; BBA 2017).

\footnotetext{
${ }^{4}$ NOM-150-SEMARNAT-2006, www.dof.gob.mx/nota detalle.php? $\operatorname{codigo}=5405315 \&$ fecha $=27 / 08 / 2015$
} 
Geothermal power production requires a geothermal resource production license issued by SENER, a water use license issued by CONAGUA (which includes the rights to drill to access the resource), and a power production license issued by the CRE. Geothermal resource production activities include drilling production wells and bringing the resource to the surface. Information about the results from the exploration stage are required as part of the production license application. Local community consultation may be required, as described in the previous paragraph. Geothermal production licenses are valid for 30 years and can be renewed. Production activities require an EIA. SEMARNAT may impose additional mitigation requirements if the project affects a conservation area (BBA 2017). Appendix A contains a list of relevant contacts in the Mexican government who could assist interested developers. The minimum requirements for geothermal registrations, permits, and licenses are listed in Appendix B.

Sensitive exploration data submitted to SENER will not be made public unless the relevant permit is revoked or expires. The Geothermal Act stipulates that geothermal activities have preference over any other land use, with the exception of oil and gas extraction, as long as the rights of the land owners and local communities are respected. The use of surface land is subject to an agreement between the geothermal company and the land owner. The government can mediate if such agreement is not reached, at the request of any of the parties.

\subsection{Renewable Energy Permitting Portal}

In April 2017, SENER plans to roll out a controlled release of ENRELmx, a portal where users will be able to complete all the required permitting processes for renewable energy projects at the federal level. SENER worked with eight other agencies to reduce the amount of time and paperwork needed to receive all the relevant federal government permits. The agencies have mapped out all the permitting steps to eliminate redundancies and reduce permitting timelines by working in parallel and automating processes when possible. SENER estimates that the unified process can shorten the permitting time by up to 35\% (Gasca Lara 2016; SENER 2016b).

Additionally, SENER has a website that describes the permits renewable energy developers must complete at www.gob.mx/tramites/energia/energias-renovables. The information provided includes costs, approximate permitting timelines, documentation needed, and instructions on how and where to complete each process. 


\section{Geothermal Energy Use in Mexico}

\subsection{Available Resource}

Estimates of the geothermal potential in Mexico vary depending on the source. SENER reports a total resource potential of $13.5 \mathrm{GW}$ (SENER 2016c). Other recent studies report a potential for conventional hydrothermal technologies between $948 \mathrm{MW}$ and 2,310 MW-not counting the current installed capacity-and between 5,250 MW and 24,700 MW in hot dry resources that require the use of enhanced geothermal system technologies (Gutiérrez Negrín 2012; Hiriart Le Bert 2011). Academic and research institutions in Mexico have received funding from the Mexican government and international entities to improve exploration and mapping techniques, and assess the available resource more accurately (see Section 2.2.2).

Figure 3 shows the estimated underground temperatures for the Mexican territory, as provided by CFE's Geothermal Power Project Management office through the analysis of data from more than 1,300 thermal points since 1983 (SENER 2016c). The map shows an area in the southeast part of the country that does not currently have a geothermal plant, near the border with Guatemala. Additionally, the map shows concentrated potential in Mexico's central region, where the Trans-Mexican Volcanic Belt and many populous cities, such as Mexico City and Querétaro, are located.

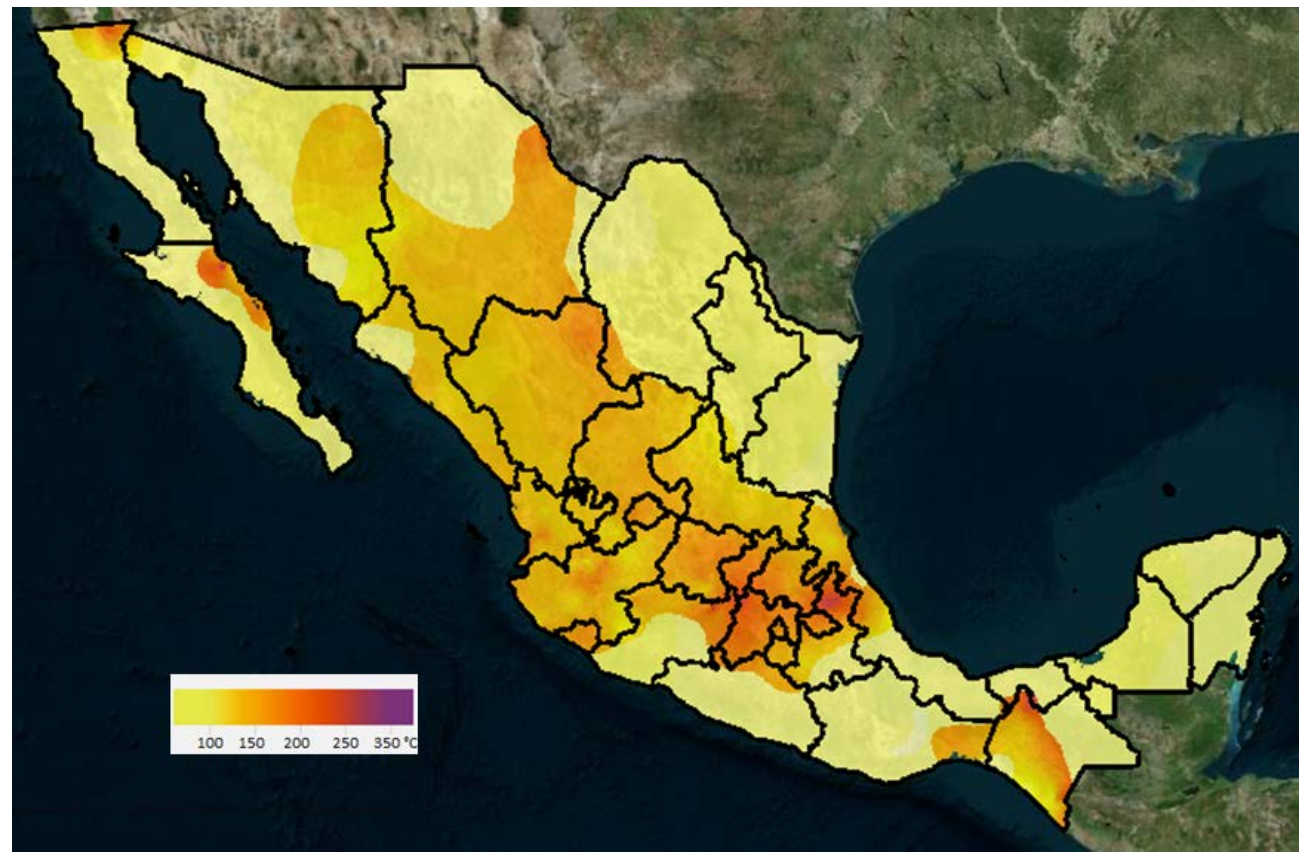

Figure 3. Estimated underground temperatures in degrees Celsius (SENER 2016c)

Figure 4 shows the estimated geothermal potential of 20 locations in Mexico that have not been used for power production, but where existing resource data may warrant further exploration. A team of researchers selected these locations according to three conditions: (1) no geothermal plants have been built in those locations, (2) the resource can be used with existing technologies, namely flash and binary geothermal plants, and (3) they have the highest estimated potential according to the data available in 2011, the year the study was published (Hiriart Le Bert 2011). 


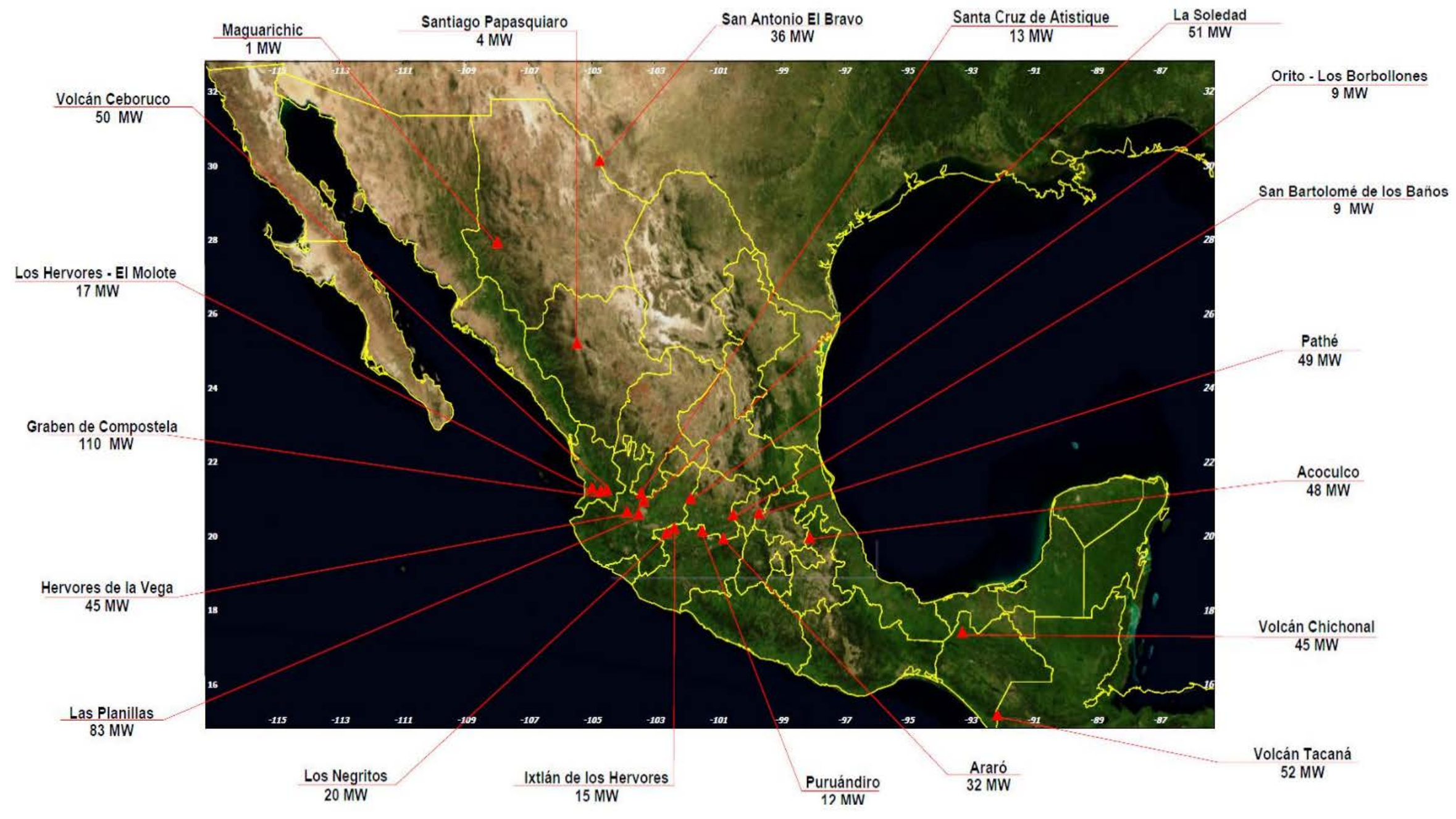

Figure 4. Map of 20 locations with high resource potential in Mexico (Hiriart Le Bert 2011) 


\subsection{Current Geothermal Capacity}

Mexico has decades of experience with geothermal energy. In 1959, Mexico installed its first geothermal power plant and has produced electricity from geothermal energy continuously since 1973 (Quijano-León and Gutiérrez-Negrín 2003). Currently, Mexico is one of the countries with the highest installed geothermal capacity in the world, with $957 \mathrm{MW}$ of installed capacity and 899 MW of operating capacity (Figure 5). Geothermal production totaled 6,032 GWh in 2016, 2.3\% of Mexico's total electricity production (SENER 2015).

Mexico's geothermal capacity is distributed between four fields owned and administered by CFE's Generation VI subsidiary (CFE VI), and one privately-owned plant (Figure 5). CFE VI has a 25MW expansion under construction in Los Humeros. Four other CFE plants with an aggregate capacity of $81 \mathrm{MW}$ are expected to come on line between 2017 and 2018 (Flores-Armenta 2016). The first geothermal project owned by a private company in Mexico, located in Domo de San Pedro, started operations in 2015. Today, the plant's operating capacity is 25.5 MW (FloresArmenta 2016).

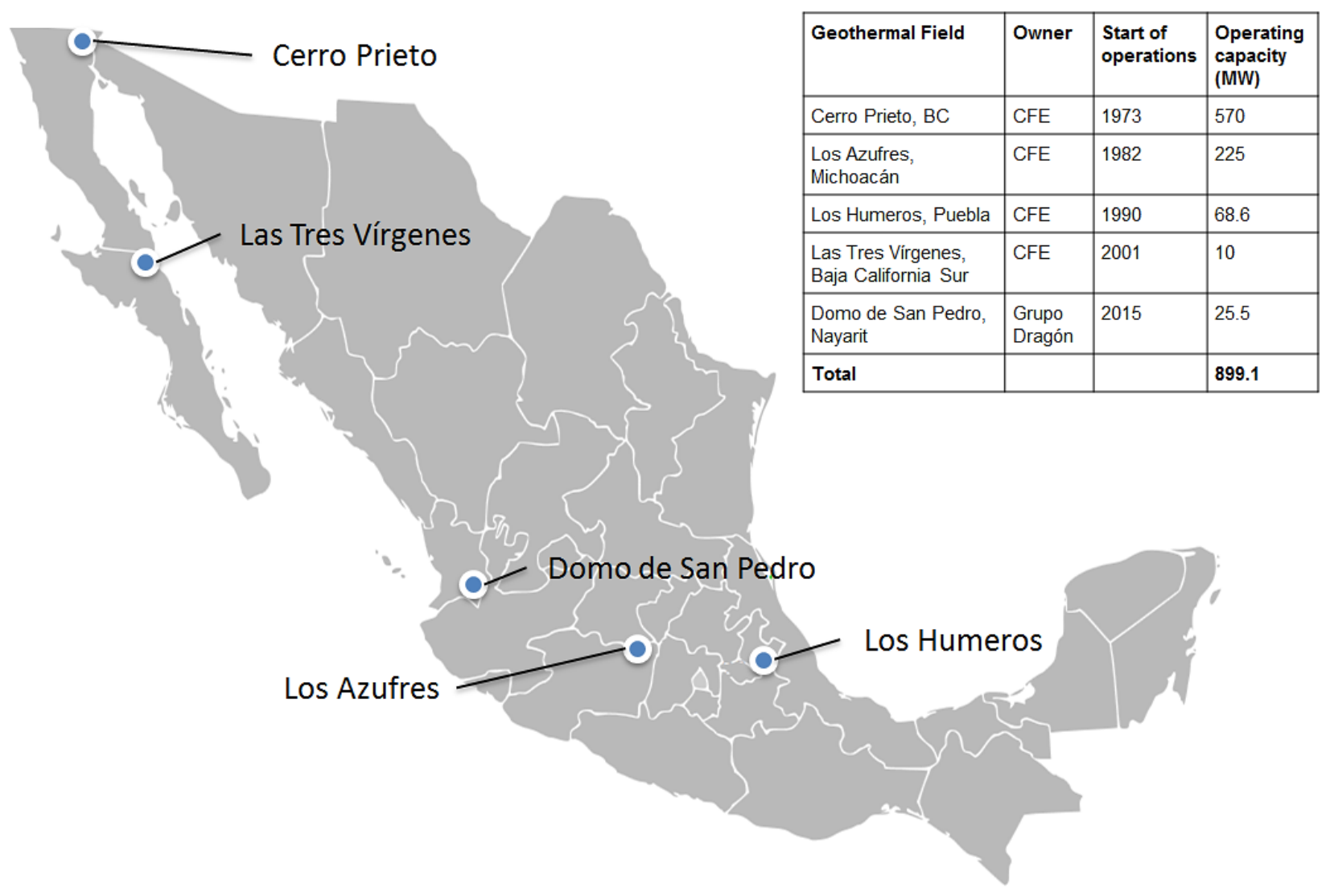

Figure 5. Geothermal fields in Mexico ${ }^{5}$ (SENER 2016c; Flores-Armenta 2016)

\footnotetext{
${ }^{5}$ Underlying map by Allstrak. Creative Commons License Attribution-ShareAlike 3.0 Unported.
} 


\subsubsection{Growth in Recent Years}

Between 1988 and 2015, geothermal development in Mexico slowed down. The compounded annual growth rate (CAGR) of geothermal capacity in Mexico between 1973 and 1988 was 16\%, and 1\% for the 1988-2015 period (Flores-Armenta 2013; Flores-Armenta and Ramírez-Montes 2015). Annual geothermal generation in Mexico peaked at 7,404 GWh in 2007 and averaged 6,044 GWh between 2012 and 2015 (SENER 2016h).

Reasons for Mexico's deceleration in geothermal deployment include the emphasis on low-cost resources and the authorization of private generation plant ownership brought about by the Public Electricity Service Law (PESL) reform of 1992. The PESL reform and the restructuring of the natural gas sector in 1995 propelled the accelerated development of natural gas plants, particularly by independent power producers (IPPs) (mostly under long-term contracts with CFE). Between 2000 and 2010, the share of privately owned natural gas plants in Mexico went from practically $0 \%$ to more than $23 \%$ of total capacity (Nieva, Prol-Ledesma, and Romo-Jones 2013; Ramírez-Camperos, Rodríguez-Padilla, and Guido-Aldana 2013; Rosellón and Halpern 1999).

The energy reforms and new geothermal regulations are designed to help reinvigorate growth in this sector. Favorable policies and streamlined regulations, plus forecasts for increasing electricity demand and up to $25 \mathrm{GW}$ of untapped geothermal potential, could help drive new investments in Mexico's geothermal energy sector. The recent restructuring of the electricity market could allow more competition and private investment, which in turn could represent an opportunity for U.S. geothermal companies and equipment manufacturers to take advantage of these new policies and existing trade agreements and help Mexico reach its ambitious targets for geothermal energy deployment.

\subsubsection{Existing Geothermal Permits and Licenses}

CFE VI holds 13 exploration permits and five production licenses. Four private companies hold a total of eight exploration permits. Grupo ENAL has one permit in the state of Guanajuato and one in Baja California; Grupo Dragón has two permits in Jalisco; Mexxus RG has one permit in Nayarit; and Storengie has two permits in Puebla and one in Nayarit. Figure 6 shows the locations of the licenses and permits granted as of March 2017.

Grupo Dragón, a Mexican renewable energy developer and independent power producer, developed the first and only operational private geothermal project in Mexico. The project is known as Domo de San Pedro and began operations in early 2015 (Rojas 2015). Grupo Dragón started the development of Domo de San Pedro years before the energy reforms had been enacted and originally planned to license and operate under the previous regulations (Ormad 2014). However, in November 2015, Grupo Dragón received the first geothermal license SENER granted under the Geothermal Act. The license allows Grupo Dragón to develop geothermal resources in Domo de San Pedro for 30 years (El Economista 2015; Richter 2016b). The project is currently operated for self-consumption, meaning that the energy is consumed by the entity that owns the plant, although not necessarily in the same location (CRE 2016). 


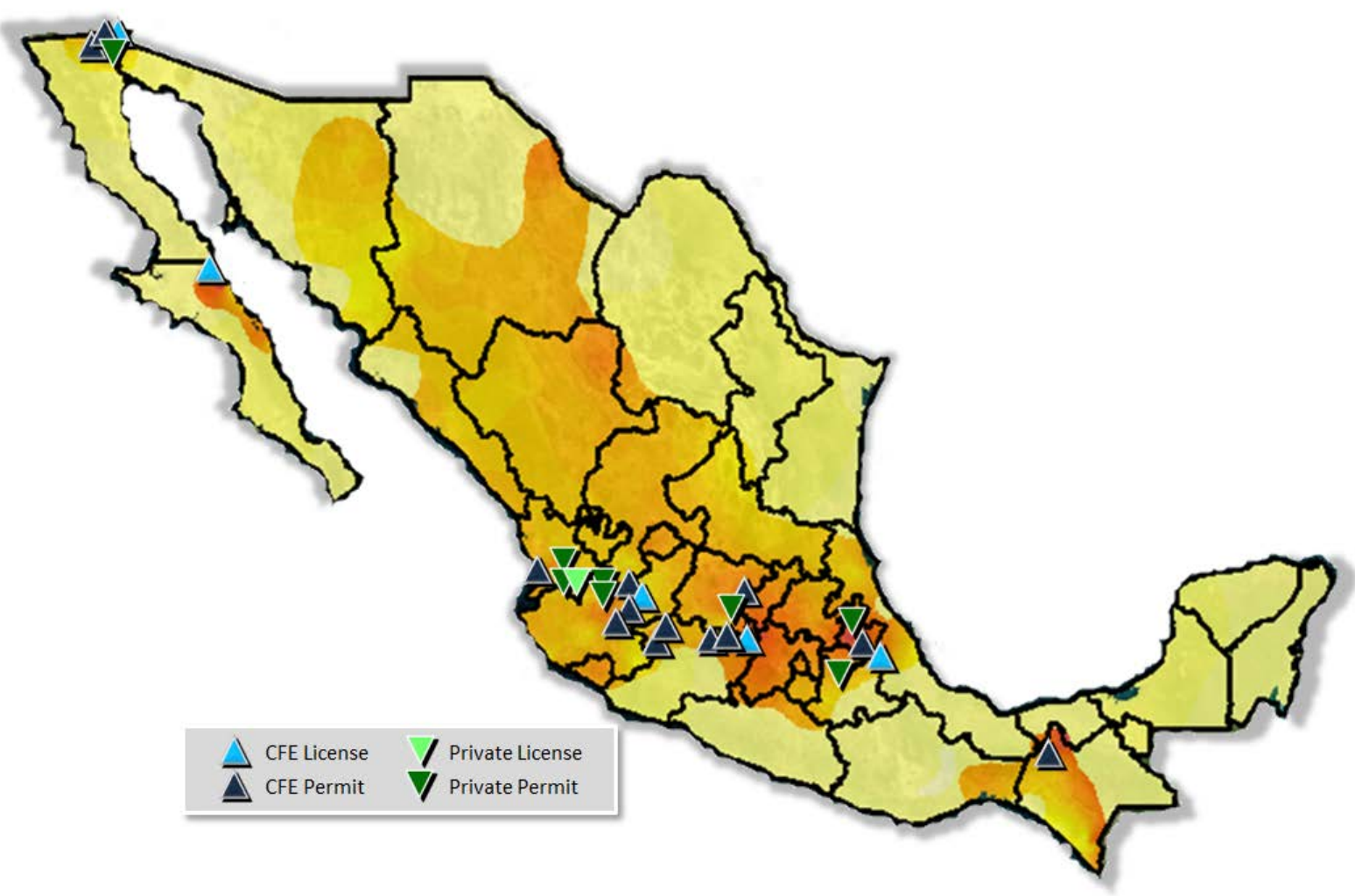

Figure 6. Approximate location of geothermal permits and licenses granted by SENER as of August 2016 (SENER 2016c) 


\section{Investment Climate, Opportunities, and Barriers}

The Mexican geothermal market could provide new investment opportunities for U.S. companies because of its proximity, resource potential, and the existing free-trade agreement between the two nations. These advantages may be amplified at every level of the value chain by the recent energy reforms and the country's substantial clean energy goals. For manufacturers of generating sets, turbines, and balance-of-plant components, the geographic proximity of the United States and Mexico and the North American Free Trade Agreement (NAFTA) may result in a strategic advantage, particularly over European competitors (see Section 3.1). The energy reform also creates new opportunities for private developers and independent power producers as described below.

\subsection{Free-Trade Agreement and Investment Climate}

Mexico is currently the third largest partner of the United States. In 2015, $\$ 531$ billion $^{6}$ in goods were traded between the two nations, which represented $14.2 \%$ of total U.S. trade (U.S. Census Bureau 2016). NAFTA eliminated all tariffs on U.S. exports to Mexico and Canada as of January 1,2008. NAFTA covers goods and services, offers intellectual property rights protection, and guarantees equal treatment to U.S. investors in Mexico and Canada (International Trade Administration 2011).

Mexico is first in the World Bank's ranking for "ease of doing business" in Latin America and the Caribbean (World Bank 2016). Mexico also received the third highest score in the same region for its clean energy policy framework, financing opportunities, availability of local manufacturing and supply chains, and greenhouse management activities (MIF et al. 2016). At about $4.35 \%$, the cost of debt for financing large-scale renewable energy projects in Mexico is the lowest in Latin America and the Caribbean. Mexico's inter-bank lending rate, 5.84\%, is also one of the lowest in the region (BNEF and MIF 2013).

\subsection{A Growing Market}

Electricity demand in Mexico is expected to grow at an average annual rate of approximately $3.5 \%$ (SENER 2015). This potential increase in demand, combined with the government's mandate for $35 \%$ of electricity to be generated with non-fossil sources by 2024 and the recent energy reforms discussed above, presents an opportunity for renewable energy investments. In 2015, investments in clean energy in Mexico reached \$4.1 billion, twice as much as in 2014, making Mexico the second largest clean energy investment destination in Latin America (BNEF 2016b). SENER projects an additional $894 \mathrm{MW}$ in geothermal capacity will be needed by 2030 to reach the country's renewable energy goals (SENER 2016f). In IRENA's REmap 2030 roadmap, $3.4 \mathrm{GW}$ of geothermal capacity (additional to the current capacity) would be needed by 2030 to reach the roadmap's goal of $46 \%$ of total electricity generated by renewable resources

\footnotetext{
${ }^{6}$ The currency used throughout this document is U.S. dollars. When the original source expressed values in Mexican pesos, the exchange rate used was \$17 MXN per \$1USD.
} 
(IRENA 2015a). Mexico's geothermal project pipeline ranks tenth worldwide, totaling $155 \mathrm{MW}$ of capacity in different stages of development ${ }^{7}$ (BNEF 2016a).

The states where SENER estimates that most of the projected geothermal capacity development will occur are shown in Figure 7. The states of Baja California (BC) and Baja California Sur (BCS) have isolated systems with high electricity prices. The states in the central part of Mexico—Nayarit (NAY), Jalisco (JAL), Michoacán (MICH), Mexico (MEX), Hidalgo (HGO), and Puebla (PUE) - have populous urban centers.

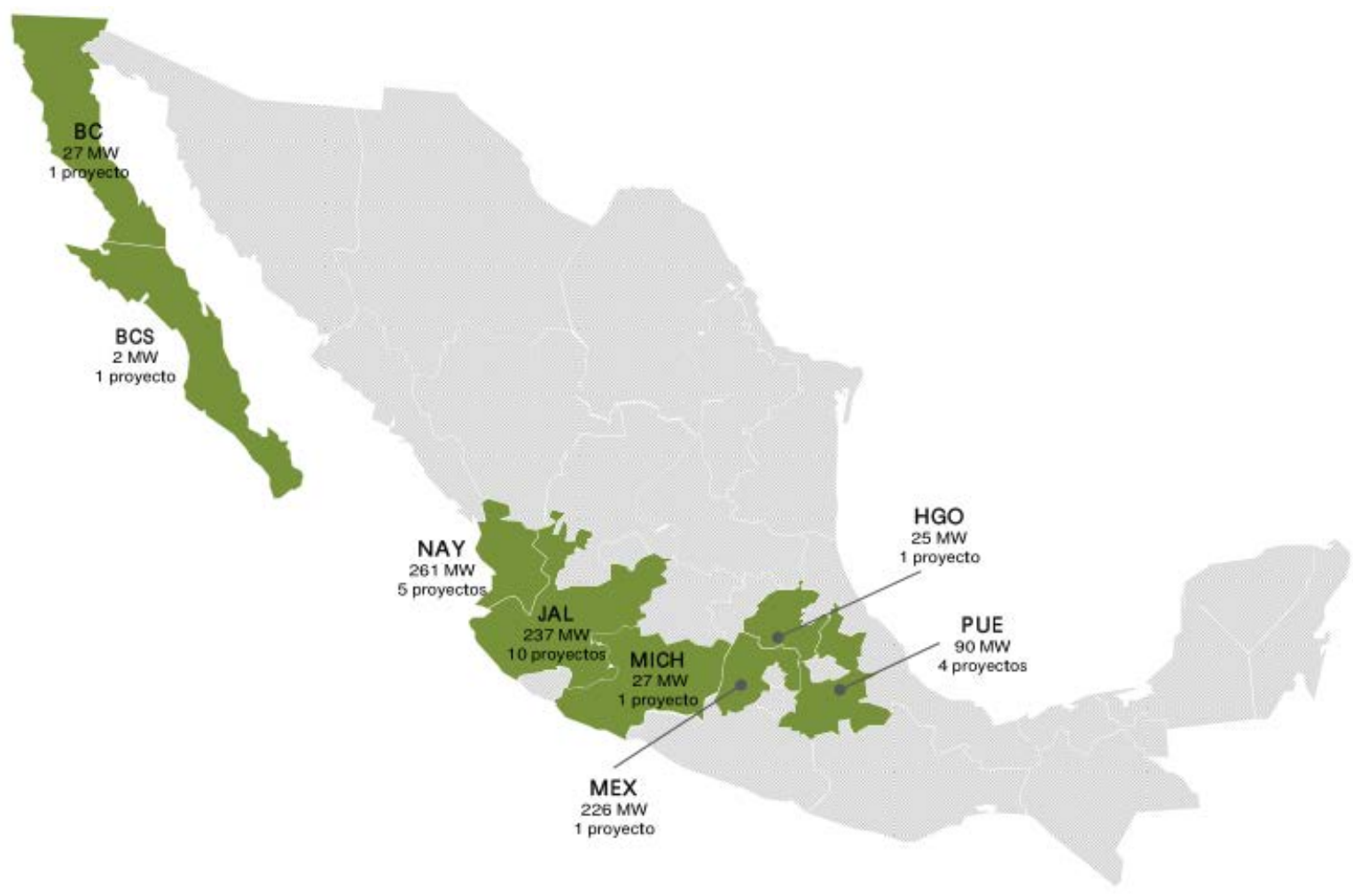

Figure 7. SENER estimates $895 \mathrm{MW}$ of additional geothermal capacity in the 2016-2030 period. "Proyecto(s)" means project(s) (SENER 2016f).

\subsection{Entrance Opportunities for Geothermal Developers and Power Producers}

There are several modalities in which private geothermal developers and power producers, ${ }^{8}$ domestic and foreign, can do business in the Mexican electricity market. In general, developers can partner with or build turnkey plants for companies that are currently operating in Mexico, or independently develop and operate new projects. Private geothermal power producers can bid in

\footnotetext{
${ }^{7}$ The stages considered in the report are 1) financing secured or under construction, 2) drilling, 3) permitted, and 4) announced. However, NREL omitted announced projects in the calculation of Mexico's project pipeline and ranking because project announcements are not necessarily a strong indication of eventual development.

${ }^{8}$ In this paper, a developer is the entity that coordinates or executes the development of a power project before operations. Power producers are the entities that own the plant during its operational life. Often, developers continue ownership of plants after they come online, thus becoming power producers.
} 
electricity auctions, sell their output in the wholesale market, or enter into bilateral contracts with CFE's generation subsidiaries, power marketers, and private, large-scale consumers. Contact the U.S. embassy in Mexico to obtain current contact information for companies active in the Mexican geothermal market (see Appendix A).

\subsubsection{Partnerships}

A potential opportunity for project developers interested in the Mexican market involves partnering with companies that currently have presence in the local geothermal market, including permit holders such as CFE's generation subsidiaries, Grupo ENAL, Grupo Dragón, Storengie and Mexxus RG (see Section 1.2). In a partnership, all parties share development and operation risks according to criteria established in the relevant contracts. Partnerships can be advantageous because locally active companies may already have permits and know the local laws, regulations, and relevant authorities. On the other hand, locally active companies have the power to set the partnership conditions or decide not to partner at all.

CFE VI is the largest geothermal permit and license holder in Mexico, with 13 permits and 5 licenses (Figure 6). As such, it could represent an important opportunity to enter the market. In general, potential partners presenting unsolicited offers to CFE or other companies could increase their chances by presenting structured and detailed proposals, finding off-takers for the energy contracts, or bringing financing resources to the partnership.

The Geothermal Act contained a provision to allow CFE to apply for geothermal exploration permits before any private entity. In 2015, SENER approved CFE's geothermal exploration permits for 13 areas, distributed in seven states (see Section2.2.2). SENER and CFE estimate that the aggregated potential of those areas is $448 \mathrm{MW}$ (Gutiérrez Negrín 2015). CFE generation subsidiaries are allowed to form public-private partnerships to develop geothermal projects in the areas approved by SENER. Alternatively, CFE generation subsidiaries are allowed to tender those areas to private developers (Flores-Armenta and Ramírez-Montes 2015). CFE's Geothermal Power Project Management office ${ }^{9}$ has expressed openness to partnering with private companies to develop and expand their reserved geothermal fields (Rojas 2014).

As mentioned in Section 1.1, CFE has been restructured into six generation subsidiaries and several other independent subsidiaries. CFE's geothermal permits and licenses have been transferred to CFE VI subsidiary. Figure 8 shows CFE's new structure.

\footnotetext{
${ }^{9}$ Gerencia de Proyectos Geotermoeléctricos
} 


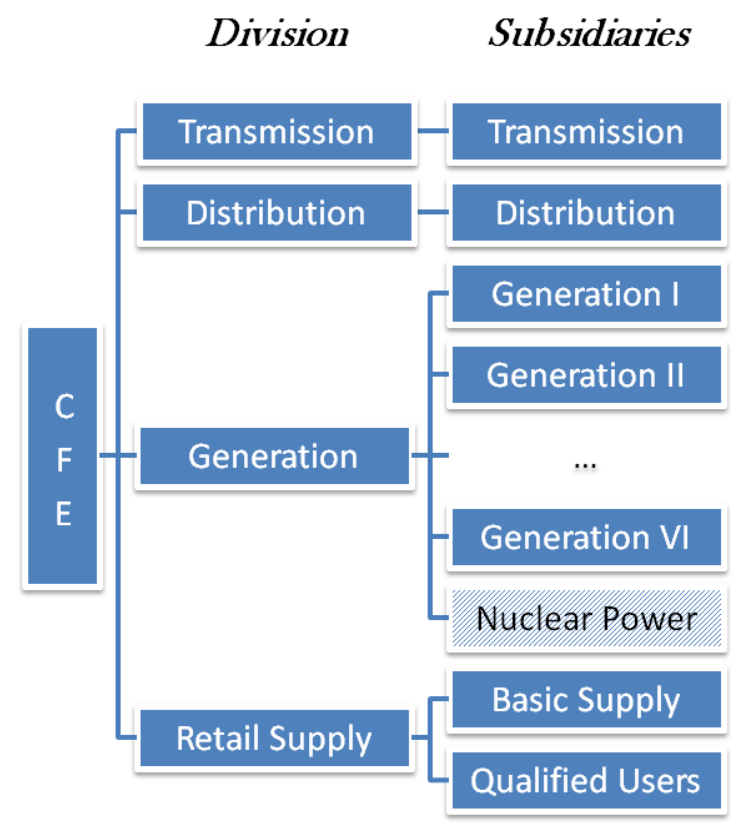

Figure 8. CFE reorganization structure. Nuclear power could be housed under CFE Generation III subsidiary or a separate business unit (Jiménez 2016; SEGOB 2016b; SEGOB 2016a)

\subsubsection{Turnkey Contracts}

Turnkey — or engineering, procurement, and construction (EPC) — is a particular form of contracting where the contractor bears the legal and financial responsibility for the design and performance of the project up until it is transferred to the client. For many years, CFE has relied on turnkey contracting to expand the capacity of its existing fields. In general, CFE requests proposals from different vendors and selects one offer according to predetermined criteria. Foreign companies have successfully bid for and signed turnkey contracts with CFE to expand geothermal fields through tendering processes (Richter 2012a; 2012c; 2012b; 2009; MHPS 2014). Other organizations also participate in the turnkey model. Grupo Dragón has a turnkey contract with Mitsubishi to install a 25-MW plant in Domo de San Pedro (Richter 2014b).

\subsubsection{Long-term Government IPP Contracts}

IPPs can enter into long-term electricity contracts with $\mathrm{CFE}$ - in its role as a power provider for end consumers - through government-led auctions. In these auctions, SENER and CENACE offer fifteen-year contracts for energy and capacity and twenty-year contracts for CELs in annual auctions (Ortiz Salgado 2016).

The government of Mexico announced the winners of its first long-term electricity contract auction in March 2016, which proved to be very competitive. SENER and CENACE received 468 offers from 103 bidders offering 16 times the energy requested. Proposed technologies included geothermal, solar PV, wind, hydro, combined cycle, and cogeneration (SENER 2016e). The winning bids include 18 projects from 11 firms, totaling an estimated energy production of $5.4 \mathrm{GWh}$ per year. Of that total, $74 \%$ was awarded to solar PV projects and the rest to wind projects. The average price of the winning bids was $\$ 47.78$ per megawatt-hour $(\mathrm{MWh})$, which includes both energy and its associated CEL (Anand 2016; McGovern 2016; Aymami 2016). 
The winning bids for Mexico's second long-term contract auction were announced in September 2016. Fifty-six projects from 23 companies were awarded contracts for CELs, energy, capacity, or a combination of the three. Of the total energy awarded, $54 \%$ went to solar projects, $43 \%$ to wind, and $2 \%$ to a geothermal project offered by CFE. ${ }^{10}$ Winning technologies also included hydropower, which took $3 \%$ of the total CELs contracted, and natural gas-combined cycle, which received $72 \%$ of all capacity contracted (SENER 2016d).

CFE's geothermal plant won contracts for CELs, energy, and capacity. The plant has a 25-MW capacity and a capacity factor of just over 90\% (Table 1). In 2018, the plant will be operational and part of CFE's existing Azufres geothermal field. The plant will receive \$25/MWh for energy and $\$ 12.5$ per CEL, plus $\$ 1,092,500$ per year in capacity payments. In total, CFE's geothermal plant will receive approximately $\$ 8.55$ million a year, an equivalent of $\$ 43 / \mathrm{MWh}$ (Richter 2016a; CENACE 2016b).

Table 1. CFE's Geothermal Winning Bid: Plant Size and Annual Revenues (Richter 2016a; CENACE 2016b)

\begin{tabular}{|l|l|l|}
\hline Capacity & $25 \mathrm{MW}$ & \multicolumn{2}{l|}{} \\
\hline Capacity factor & $90.5 \%$ & \multicolumn{2}{l|}{} \\
\hline Annual energy production & $198,764 \mathrm{MWh}$ & Per unit \\
\hline & Annual total & $\$ 25 / \mathrm{MWh}$ \\
\hline Energy revenues & $\$ 4,969,100$ & $\$ 12.5 / \mathrm{MWh}$ \\
\hline CEL revenues & $\$ 2,484,550$ & $\$ 43.7 / \mathrm{kW}$ \\
\hline Capacity revenues & $\$ 1,092,500$ & \\
\hline Total revenue & $\$ 8,546,150$ & \\
\hline Approximate revenue per MWh & $\$ 43.00$ & \\
\hline
\end{tabular}

Levelized cost of electricity (LCOE) estimates for flash steam power plants in Mexico range between $\$ 57 / \mathrm{MWh}$ and $\$ 84 / \mathrm{MWh}$, and between $\$ 50 / \mathrm{MWh}$ and $\$ 107 / \mathrm{MWh}$ for binary plants. ${ }^{11}$ Although it could be difficult for geothermal plants to compete with prices set by solar and wind projects in Mexico's energy auctions, particularly for greenfield developments (Gutiérrez Negrín 2016; IRENA 2015b), geothermal field expansion development can be built at lower costs (IRENA 2015b), as shown by CFE's offer in Mexico's second long-term contract auction. The competitiveness of geothermal plants in Mexico's electricity auctions may depend in part on the ability of developers to keep their exploration, construction and operation costs down; to reduce financing costs through Nafinsa's risk-reduction program (described in Section 4.3) and other financing mechanisms (see Section 4.1); and to obtain favorable prices in capacity contracts. The government's third long-term contract auction will open at the end of April 2017 and results will be announced in October of the same year (Díaz López 2017).

\footnotetext{
${ }^{10}$ The offer was submitted by CFE before restructuring. The plant will be administered by CFE VI.

${ }^{11}$ These estimates do not include CELs or the benefits of any incentives or risk reduction programs.
} 


\subsubsection{Power Purchase Agreements}

IPPs can sign PPAs with qualified users, defined by law to be commercial and industrial consumers with a peak demand of $1 \mathrm{MW}$ or more. PPA terms and conditions, such as length and price, are set by the parties to the contract and are not regulated by the government, provided that they comply with Mexican law (BBA 2017). Users wishing to be qualified need to register with the Energy Regulatory Commission (CRE ${ }^{12}$ ) (CRE 2015). End-users with a peak demand of 5 MW or more can also procure electricity in the wholesale energy market.

In principle, the new CFE generation subsidiaries are allowed to sign PPAs directly with IPPs outside of government-run auctions. ${ }^{13}$ For decades under the old regulations, CFE routinely signed PPAs with IPPs. However, because CFE generation subsidiaries must now compete with other producers, new PPAs would create risk for CFE and transfer the responsibility of looking for an off-taker to CFE. Therefore, a partnership in which both the developer and CFE subsidiaries work together on building the plant and looking for off-takers could be a more compelling approach for CFE (López Pineda 2016).

\subsubsection{Participation in the Wholesale Market}

IPPs can also participate directly in the Mexican wholesale electricity market, which includes markets for energy and ancillary services. Some of CFE's geothermal generation stations participate in the wholesale electricity market. As of March 2017, no geothermal IPPs participate.

IPPs participating in the wholesale market will be exposed to price volatility and its financial risks. In the United States, geothermal developers have favored long-term power sales contracts over competitive markets. Long-term contracts help geothermal developers hedge against the price volatility of wholesale markets. The lower risks associated with long-term contracts also help in obtaining better financing terms, which is particularly important for geothermal development given high upfront capital expenses and cost of capital (Gehringer and Loksha 2012; Sener, Dorp, and Keith 2009). Price risk may also be managed through alternative hedging strategies, such as synthetic power purchase agreements where the risk is transferred to a third party.

While there are risks with participating in the wholesale market, geothermal plants are capable of providing diverse ancillary and value-added services, such as higher ramp rates, inertia, dispatchability, voltage regulation, and reactive power (Trabish 2013). These services could help producers increase the revenues they receive from the market. The ancillary services currently traded in the Mexican market include regulation (via automatic generation control), spinning reserves, non-spinning reserves, and supplemental reserves (CENACE 2016a).

\subsection{Entrance Opportunities in the Geothermal Value Chain}

The geothermal supply chain in Mexico is relatively well developed, despite the weak capacity growth of the last decades described in Section 2.2.1 (MIF et al. 2015). An analysis commissioned by the Mexican chapter of the World Business Council for Sustainable

\footnotetext{
${ }^{12}$ Comisión Reguladora de Energía

${ }^{13}$ SENER and CENACE will auction PPAs with CFE at least once a year; see Section 5.3.4.
} 
Development estimates that the supply chain in Mexico is currently able to supply geothermal components and services worth $72 \%$ of the total investment required to comply with clean energy targets (PwC 2015a). Gaps in the current supply chain were identified in segments such as operations and maintenance (O\&M) services, engineering services, and drilling services (ITA 2016b). Furthermore, while the degree to which Mexico's recent energy reforms will lead to substantial growth in the geothermal sector remains unknown, any significant increase in demand should create opportunities for new market entrants, even in subsectors relatively close to saturation in current conditions.

The strong presence of the oil and gas industry in Mexico represents both an opportunity and a threat to companies operating in the geothermal sector. The oil and gas industry uses drilling equipment and expertise similar to the geothermal sector, which should increase the availability of those resources in Mexico. However, high demand for this equipment and expertise could also lead to increasing costs (ESMAP 2012). As Mexico's energy reforms have also opened up the country's oil and gas markets to foreign investments, oil production in Mexico is forecast by the IEA to increase by as much as $75 \%$ by 2040 , which could indirectly increase the demand and cost of drilling services and equipment for the geothermal sector (Doman and Singer 2014).

\subsubsection{Entrance Barriers}

Barriers to entry for U.S. companies described in this section do not preclude companies from participating in any subsector of the Mexican geothermal market, even when they are high. However, these indicators signal that entering a certain market or subsector may carry higher costs for most companies. Companies able to present a competitive advantage would face low or no barriers to entry. For example, companies that provide integrated solutions that efficiently utilize low-enthalpy resources could encounter limited competition because the targeted and customized application of such innovative technologies does not seem readily available in Mexico.

In this analysis, barriers to entry are assessed in two main categories: exports and services. Tables 2 and 3 present the relative barriers foreign companies could face in entering the Mexican market under current conditions. Potential barriers to entry are estimated using two criteria. The first criterion uses an estimation of market saturation, which is directly correlated to barrier levels. This means that the higher the number of competitors estimated to be currently active in a given chain subsector - relative to what represents market saturation - the higher the barrier to entry.

The second criterion looks at all other barriers and opportunities that a foreign participant wishing to enter the Mexican market would encounter independently of market saturation conditions in Mexico. For example, geothermal drilling does not appear to be a subsector with many active competitors in Mexico (BNEF and MIF 2013). However, moving or acquiring drilling equipment for geothermal exploration and development represents a significant investment. A foreign drilling company would have to assess the long-term business opportunities that would justify such a decision. That assessment would be difficult under current conditions because Mexico's energy reforms changed the market conditions very significantly and recently. Both the uncertainty related to the long-term prospects of the geothermal market in Mexico and the high level of investment needed represent a relatively elevated barrier to entry. On the other hand, a supplier can successfully enter into a saturated segment of the supply chain 
if it is able to provide a component or service at a lower cost for the same level of quality, or a higher quality level for the same cost.

Overall, exports from U.S. companies face lower barriers to entry mainly because of NAFTA and the geographic proximity of the United States and Mexico, which translate into lower shipping rates and times, and zero tariffs assessed on U.S. equipment. However, Japanese and European turbine manufacturers have longstanding commercial relationships in the country, which may increase the barriers to entry for U.S. manufacturers. The U.S. International Trade Administration (ITA) anticipates that the greatest opportunities for U.S. companies will be in providing goods and services related to early-stage geothermal development (e.g., exploration and test drilling) and improving efficiency in operations at existing plants that have experienced reductions in production (ITA 2014). See Section 5.1 for more information about ITA.

\section{Table 2. Relative Barriers for Foreign Companies to Export Manufactured Goods to the Mexican} Geothermal Market

\section{Relative Barriers for Exports}

Exports in general represent a good opportunity for U.S. companies because of the proximity of Mexico and the free trade agreement between the two countries.

\begin{tabular}{|c|c|}
\hline \multirow[t]{2}{*}{$\begin{array}{l}\text { Turbines } \\
\text { and } \\
\text { Generators } \\
\text { (Gensets) }\end{array}$} & $\begin{array}{l}\text { Market saturation - Medium to high } \\
\text { Mexico has very well established players in the turbine subsector. Alstom }{ }^{14} \text { and } \\
\text { Mitsubishi Hitachi have supplied turbines to more than } 16 \text { plants. Globally, three } \\
\text { Japanese companies have supplied } 80 \% \text { of all gensets sold to date (ESMAP 2012). }\end{array}$ \\
\hline & $\begin{array}{l}\text { Other barriers - Low } \\
\text { Providers of integrated solutions could participate at an equal level as any other bidder } \\
\text { in CFE tenders, or participate individually. Other manufacturers could partner with } \\
\text { other participants. }\end{array}$ \\
\hline \multirow[t]{2}{*}{$\begin{array}{l}\text { Balance of } \\
\text { Plant (BOP) }\end{array}$} & $\begin{array}{l}\text { Market saturation - Medium } \\
\text { BOP components used in geothermal development are relatively standard and } \\
\text { common to other industries. The market for these components in Mexico has } \\
\text { established players. }\end{array}$ \\
\hline & $\begin{array}{l}\text { Other barriers - Low } \\
\text { Given the proximity of the two countries, U.S. companies would not be at a competitive } \\
\text { disadvantage as potential suppliers of BOP components. }\end{array}$ \\
\hline
\end{tabular}

Low

Medium

High

The strongest segments of the services value chain in Mexico are project development, construction, and O\&M (Table 3). Alstom/GE and Mitsubishi have developed hundreds of megawatts of capacity for CFE in the last 15 years. Iberdrola - a Spanish company with 5,400 MW of wind and natural gas generation capacity installed in Mexico - teamed with Alstom to bid for a turnkey project in Mexico in 2012 (Martínez 2016). ENEL Green Power-an Italian renewable energy developer that was awarded $42 \%$ of the total capacity up for bid in Mexico's first energy auction - built and operates more than 1,000 MW of geothermal capacity in Italy, the

\footnotetext{
${ }^{14}$ Alstom was recently acquired by GE.
} 
United States, and El Salvador (ENEL Green Power 2013; 2016). At least 10 domestic and international - mostly European - developers active in these subsectors participated in a 2012 geothermal development policy initiative marshalled by SENER (SENER 2012a).

Table 3. Relative Barriers for Foreign Service Providers to Enter the Mexican Geothermal Market

\section{Relative Barriers for Services}

The services value chain is not overly saturated in Mexico. However, it is rated as a "medium" barrier because several companies have been participating in the Mexican renewable energy market for years or decades.

\begin{tabular}{l|l} 
Exploration & $\begin{array}{l}\text { Market saturation - Medium } \\
\text { Local companies and personnel have decades of experience. CEMIE-Geo is funding } \\
\text { Mexican scientists to complete geothermal exploration projects and develop new } \\
\text { exploration techniques (see Section 2.2.2). }\end{array}$ \\
\cline { 2 - 3 } & $\begin{array}{l}\text { Other barriers - Low } \\
\text { Private U.S. companies that demonstrate a high level of expertise could participate } \\
\text { individually or partner with developers. }\end{array}$
\end{tabular}

Engineering
and Project
Management

Market saturation - Medium

Geothermal reservoir engineering is a very specialized field. However, local companies are active and have decades of experience in different geothermal power
technologies (e.g., binary, steam-flash, etc.) (a)

Other barriers - Medium

U.S. companies may have to identify a strong partner. Companies capable of designing plants that work with difficult or low-temperature fluids could face less competition (ESMAP 2012).

\begin{tabular}{|l|l|}
\hline Drilling & \\
& \\
\hline Construction
\end{tabular}

Market saturation - Low

Geothermal drilling does not appear to be a subsector with many active competitors in Mexico (BNEF and MIF 2013). However, with 18 permits recently issued, conditions may change rapidly.

Other barriers - High

Moving the drilling equipment required for geothermal exploration and development is expensive and dependent on long-term business viability.

Construction

Market saturation - High

Once the wells have been finished, building a geothermal power plant is not a highly specialized task. There are many active participants in the Mexican market.

Other barriers - Medium

Construction is very dependent on local labor and materials. However, this could represent an opportunity for foreign companies willing to partner with local companies.

O\&M $\quad$ Market saturation - Medium

Several companies specializing in geothermal O\&M are active worldwide, often with the support of local companies (ESMAP 2012). There is substantial expertise in Mexico, where geothermal plants have been continuously operated and maintained since 1973.

Other barriers - Medium to high 


\section{Mexican Government Programs, Resources, and Incentives}

\subsection{Investment Guidance for Foreign Companies}

The government of Mexico has established ProMéxico, an office dedicated to providing assistance to foreign companies interested in pursuing business opportunities in Mexico. ProMéxico provides step-by-step guidance regarding all aspects related to conducting business in Mexico, from getting a visa and incorporating a business in Mexico to identifying investment and tax incentives applicable to specific situations.

ProMéxico has offices in 12 cities of the United States, and its agents can be contacted via chat through their website, www.promexico.mx. More information about contacting ProMéxico is included in Appendix A.

\subsection{Tax Incentives and Financing Mechanisms}

Renewable energy producers are eligible for a $100 \%$ up-front federal tax deduction for the cost of investments in equipment made in 2016 and 2017. This deduction reduces the investor's federal tax liability and is equivalent to an accelerated depreciation with a schedule of one year. The corporate tax rate in Mexico is 30\% (KPMG 2016). Eligible technologies include solar, geothermal, PV, wind, biomass, and hydro (PwC 2015b; Grageda Nunez 2015). All power sales in Mexico are subject to a $16 \%$ value-added tax (VAT). However, VAT paid as part of business operations can offset net VAT collected by the government (BBA 2017).

The Mexican government has created new investment vehicles — and modified existing ones - to increase the availability of financing for energy projects, create legal certainty for investors, and simplify tax obligations. The first of the newly available vehicles, FIBRA E (infrastructure and real estate trusts), is based on the Real Estate Investment Trusts (REIT) used in the United States. FIBRA E trusts pay out the taxable income from their generation plants as dividends to shareholders. FIBRA E allows any investor to participate in renewable energy financing and possibly obtain a return on the investment through the purchase of stock (Grupo BMV, n.d.; Deloitte 2016).

Another financing vehicle, the CerPI (investment project certificate), is designed to open access to sources of capital previously unavailable to renewable energy project finance such as pension funds, insurance funds, and other foreign and domestic institutional investors. CerPIs are structured through Mexican trusts that issue investment certificates placed through a public offering on the Mexican Stock Exchange (Groenewold 2012; Deloitte 2016). FICAPs (investment trusts for private capital) are vehicles for private equity investment that provide the trust members with tax-transparent benefits; that is, trustees are taxed on the distribution received and not on the portion of the trust income to which the beneficiary is entitled. Their goal is to promote investment in companies that are not listed on the stock exchange at the time of investment. FICAP trusts used to have a time limit of 10 years, which limited their appeal to investors. The 2016 tax reform has eliminated that cap. As a result, energy projects with operational lives longer than 10 years can raise capital through these instruments (Grageda Nunez 2015; Tron and Scheffler 2016; Deloitte 2016). 
Mexican development banks, such as Banobras and Nafinsa, and multilateral development banks, such as the Inter-American Development Bank (IDB), the International Finance Corporation, and the North American Development Bank, could be a source of low-cost debt financing for renewable energy projects in Mexico (ITA 2016c). One risk for geothermal development is that it will be competing with other renewable energy technologies for a limited pool of financing and long-term contracts. However, the energy reforms, the Geothermal Act, financing mechanisms, the exploration risk mitigation program, and other measures described in this section could help make geothermal a more attractive option for investors.

\subsection{Exploration Drilling Risk Mitigation Mechanism}

A problem geothermal development experiences worldwide is the difficulty of raising capital for exploration and initial test drilling due to the risks involved at this stage (Sanyal et al. 2016). SENER, Nacional Financiera (Mexico's national development bank, also known as Nafinsa), Munich RE, and the IDB have established a revolving fund and third-party guarantee mechanism to reduce geothermal exploration risks for geothermal developers. The goal is to lower the cost of access to capital for geothermal development during the initial stages (IDB 2014).

SENER, IDB, and the Clean Technology Fund (CTF) contributed \$11.4 million, \$54.3 million, and \$54.3 million dollars, respectively, to the program. The Geothermal Investment Fund (GIF) will be used as a revolving fund to finance high-risk, high-cost phases of geothermal development, as well as power plant construction. The fund will be replenished by repayments from successful projects (Figure 9). GIF funds will finance up to three wells in the exploratory drilling phase and up to five wells in the production drilling phase (Nacional Financiera 2015).

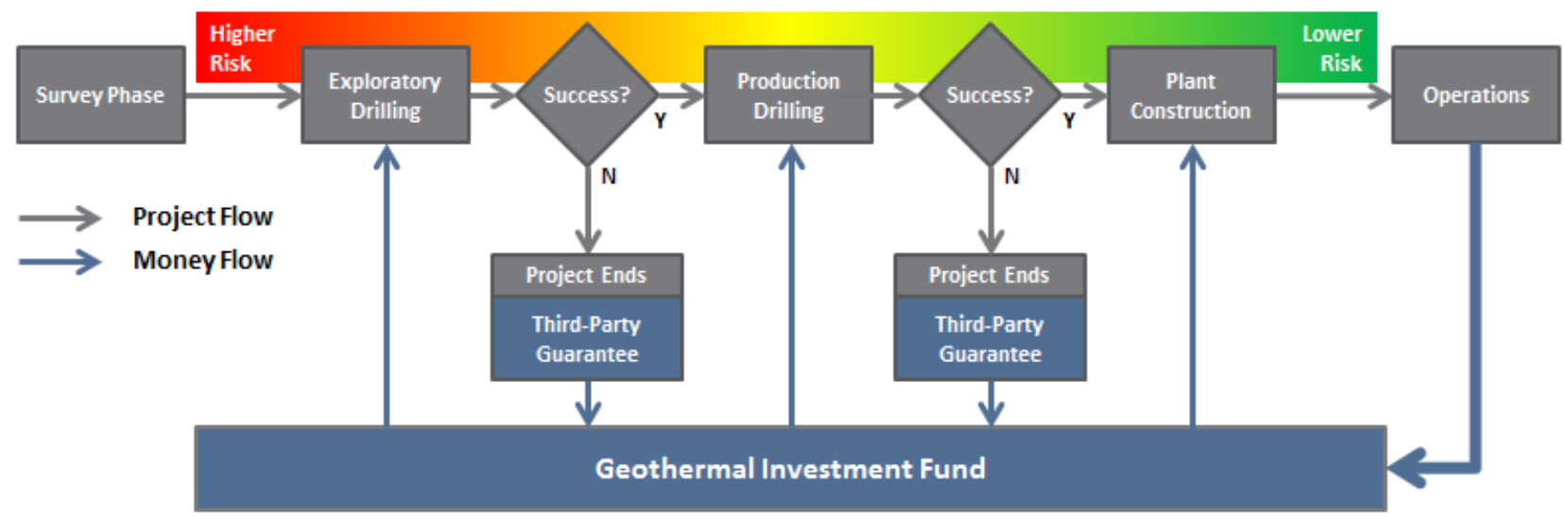

Figure 9. Project and money flow under the drilling mitigation mechanism program

A phase-gate process will be used to decide what projects continue receiving financing from the GIF. Funding will cease for projects that fail to meet GIF's resource productivity targets after the wells have been drilled. SENER, Munich RE, and CTF will guarantee the funds used to finance exploratory and production drilling through a third-party guarantee mechanism, which will repay funding lost on failed projects. The program will reduce its exposure to risk by assessing the financial and technical viability of each project and by requiring developers to share the financial risk. Munich RE has developed similar credit guarantee mechanisms in other countries (Richter 2014a; IDB 2014; Nacional Financiera 2015). Companies interested in this mechanism should contact Nafinsa directly. Appendix A contains relevant contact information. 


\subsection{Clean Energy Certificates}

Under the law, the CRE is empowered to issue CELs, which are used to track compliance with the country's clean energy requirements. Electricity retailers, including CFE and power marketers, qualified users, wholesale market participants, and PPA off-takers are required to meet annual CEL obligations, which are established by SENER. During the first compliance year CY 2018, energy market participants will be required to obtain 5\% of electricity generation from clean energy sources; percentage requirements are then expected to increase in out-years (Miller 2015; PV Magazine 2016; Sternthal 2016). Power plants that produce renewable and nuclear energy, as well as cogeneration plants, are eligible to receive one CEL with a 20-year shelf life per MWh produced. CELs are tradable in a market operated by CENACE. Fines for noncompliance will range from $\$ 27$ to $\$ 230$ per MWh (PwC 2014; Lexology 2015).

CELs could improve project economics for geothermal plants and their competitiveness in relation to fossil-fuel generation. CELs have not been traded yet in the open market and there are no reliable indications of what their price in the open market might be. In the first long-term contract auction, the average price per CEL was $\$ 16.44$; it was $\$ 13.08$ in the second auction (EY 2016).

\subsection{National Renewable Energy Inventory and Atlas}

The National Inventory of Renewable Energy ${ }^{15}$ (INERE) is an interactive map that can assist developers in identifying the areas in the country with the highest resource potential for solar, wind, geothermal, hydro, and biomass technologies. The goals of INERE include inventorying the best renewable energy resources in the Mexican territory, and assisting developers and investors in locating those resources. The Clean Energy Zones Atlas ${ }^{16}$ is a complementary map that shows 601 geothermal sites identified by the National Autonomous University of Mexico as having a high potential based on hydrothermal manifestations. The sites can be filtered according to their distance from the closest point of interconnection with the transmission system. Users can select other layers relevant to power development, including natural hazard zones, protected natural areas, and land use.

\footnotetext{
${ }^{15}$ The INERE interactive map can be accessed at https://dgel.energia.gob.mx/inere/ (requires Adobe Flash Player)

${ }^{16}$ Atlas de Zonas de Energías Limpias: https://dgel.energia.gob.mx/azel/ (requires Adobe Flash Player)
} 


\section{U.S. Government Resources}

\subsection{International Trade Administration}

The International Trade Administration (ITA), a division of the U.S. Department of Commerce, supports U.S. industry competitiveness and fair trade in international markets with the objective of increasing U.S. exports globally. ITA conducts broad market analysis, engages in trade negotiations, and supports activities to reduce trade barriers for American companies. ITA also has staff located in embassies and consulates around the world as well as in many cities throughout the United States. Staff at these offices can assist U.S. companies in arranging meetings with potential buyers, distributors, or partners in foreign countries. Additionally, ITA can provide assistance to U.S. companies in setting up contracts with foreign companies.

ITA releases a renewable energy market assessment annually. The publication 2016 Top Markets Report: Renewable Energy was released in April 2016 (ITA 2016a). The publication includes an assessment of market opportunities internationally, as well as a targeted section on geothermal opportunities around the world. The report ranks Mexico second worldwide in terms of geothermal market opportunities for U.S. companies.

U.S. geothermal companies interested in ITA's support can contact either a domestic office (http:/export.gov/usoffices/index.asp) or the Foreign Commercial Services office located in the U.S. Embassy in Mexico City (https://mx.usembassy.gov/business/getting-started-mexico/). Additional contact information can be found in Appendix A.

\subsection{Department of State}

The U.S. Department of State (DOS) provides general resources about specific countries and markets. DOS staff located within the U.S. Embassy in Mexico City coordinates with ITA's Foreign Commercial Services staff to support U.S. exports to and investments in Mexico. In general, DOS encourages U.S. companies to contact Foreign Commercial Services directly, whose staff will bring in DOS experts as appropriate and based on the company's needs. The DOS staff can provide an economic and political overview of specific markets.

The U.S. Embassy in Mexico City launched a business opportunities website in April 2014 designed to support small and medium enterprises. The website, called "Opportunities in Mexico for U.S. Businesses and Investors," is located at https://mx.usembassy.gov/business/. This resource provides financial, economic, and political updates on issues related to U.S. business opportunities in Mexico. It also provides resources for businesses interested in exporting to or investing in Mexico. Though the information provided covers all sectors, there are many resources relevant to energy companies.

\subsection{Overseas Private Investment Corporation}

The Overseas Private Investment Corporation (OPIC) supports U.S. businesses by providing medium- to long-term debt financing, political risk insurance, and investment support to companies expanding into emerging markets, including Mexico. OPIC is able to loan up to \$250 million per project in countries where conventional financial institutions are reluctant or unable to lend due to market uncertainties. Eligible projects must have meaningful involvement with the U.S. private sector, which is often satisfied by at least $25 \%$ of the project company's equity coming from U.S. businesses, citizens, or lawful permanent residents. 
OPIC's political risk insurance program helps U.S. companies, investors, lenders, contractors, exporters, and nongovernmental organizations reduce the risk of investing in a developing or emerging market by protecting tangible assets, investments, and earnings from losses that result from activities outside of the control of the investor. These activities could include war, political violence, expropriation, and currency inconvertibility.

Since 2010, OPIC has committed over \$1 billion annually to renewable and clean energy projects across the globe. That portfolio includes debt financing to the first privately financed geothermal project in Africa, located in Kenya's Hell's Gate National Park. OPIC is able to support geothermal projects from the point at which the resource levels are proven through independent reservoir reports and well flow tests (Rhazi 2016).

For more information, visit: www.opic.gov/.

\subsection{Export-Import Bank}

The Export-Import Bank (Ex-Im) supports the export of U.S. products and services. Renewable energy is a key industry for Ex-Im (Ex-Im Bank 2016b). The bank's Renewable Express program provides post-completion project financing of up to $\$ 10$ million. This program uses a streamlined procedure to evaluate and underwrite the borrower's credit in 60 days or more (Ex-Im Bank 2016c).

The Environmental Exports Program is designed to provide financing for U.S. companies exporting environmental technologies and services, including renewable energy. Through this program, Ex-Im provides the following financing support:

- Short-term working capital

- Export credit insurance

- Medium-term insurance

- Medium- to long-term loan guarantees

- Projects and structured finance

- Long-term direct loans (Ex-Im Bank 2016a).

Additionally, transactions may be eligible for capitalized interest during construction and allowing for up to $30 \%$ local cost financing.

To learn more and to contact an Ex-Im Bank representative directly, visit www.exim.gov/learning-resources.

\subsection{U.S. Trade and Development Agency}

The U.S. Trade and Development Agency (U.S. TDA) focuses on assisting U.S. companies export goods and services to developing and middle-income countries. U.S. TDA provides technical assistance and funding for global infrastructure feasibility studies and pilot projects. U.S. TDA activities include linking U.S. businesses with global infrastructure opportunities, providing grants to overseas sponsors for priority infrastructure projects, providing a diverse array of technical assistance, building mutually beneficial trade and investment partnerships in 
developing economies, and identifying economic sectors globally that represent the greatest opportunity for U.S. companies. U.S. TDA has also established partnerships with more than 100 trade promotion organizations in the United States to gather market intelligence on U.S. small and medium-sized companies and to connect them with foreign markets. U.S. TDA considers the energy industry as a priority sector and supports efforts in partner countries to develop renewable energy resources. In Fiscal Year 2015, USTDA committed over half of its energy investments to renewable power. Mexico is one of U.S. TDA's 20 priority countries (U.S. TDA 2016; U.S.

TDA 2017)

\subsection{Border Environment Cooperation Commission and North American Development Bank}

The Border Environment Cooperation Commission (BECC) and the North American Development Bank (NADB) are binational institutions created by the governments of the United States and Mexico under a side agreement to NAFTA. Their main goal is to preserve and enhance environmental and social conditions along the U.S.-Mexico border. Both organizations work in tandem to develop, finance, and build self-sustaining projects. BECC focuses on the technical aspects of project development, while NADB provides financing and implementation oversight. BECC and NADB have assisted 234 projects and leveraged a total of $\$ 7.8$ billion in infrastructure investment. BECC and NADB have worked with municipal, state, and federal governments, as well as the private sector, to develop, certify, and finance 13 renewable energy and energy efficiency projects with a total capacity of almost $800 \mathrm{MW}$. These institutions provide:

- Technical assistance grants

- Project certification

- Loans for infrastructure projects

- Grant financing for projects in all environmental sectors.

More information is available at www.nadbank.org/ and www.becc.org/. 


\section{References}

Anand, Mohit. 2016. "Solar Stuns in Mexico's First Clean Energy Auction: 1,860MW Won at \$50.7 per MWh.” April 5. http://www.greentechmedia.com/articles/read/Solar-Stuns-inMexicos-First-Clean-Energy-Auction-1860-MW-Won-at-50.7-P.

Aymami, Joan. 2016. "Reflections on the First Renewable Energy Auction in Mexico." AWS Truepower. https://www.awstruepower.com/blogs/smarter-power/reflections-on-the-firstrenewable-energy-auction-in-mexico/.

BBA. 2017. "Geothermal Transparency Guide." https://issuu.com/bba3/docs/geothermaltransparency-guide_web?reader3 $=1$.

Bierzwinksy, Rachel, David Jiménez, and Javier Félix. 2014. "A New Power Market in Mexico." http://www.chadbourne.com/sites/default/files/publications/new_power_market_mexico_ 0914.pdf.

BNEF. 2016a. "2016 Geothermal Market Outlook."

—. 2016b. "Climatescope - Mapping the Global Frontiers for Clean Energy Investment." https://energydata.info/dataset/climatescope-mapping-the-global-frontiers-for-cleanenergy-investment-2016.

BNEF, and MIF. 2013. "ClimateScope 2013, New Frontiers for Low-Carbon Energy Investment in Latin America and the Caribbean." climatescope.fomin.org.

CENACE. 2016a. "Precios Marginales Locales." http://www.cenace.gob.mx/SIM/VISTA/REPORTES/ServConexosSisMEM.aspx.

- 2016b. "Subastas Largo Plazo." http://www.cenace.gob.mx/Paginas/Publicas/MercadoOperacion/SubastasLP.aspx.

CRE. 2015. "Preguntas frecuentes sobre la nueva regulación en temas eléctricos." http://www.cre.gob.mx/documento/faq-regulacion-electricos.pdf.

— 2016. "Tabla de permisos de generación e importación de energía eléctrica administrados al 30 de junio de 2016." http://www.cre.gob.mx/documento/1814.xlsx.

Deloitte. 2016. "FIBRA E, CerPI y FICAP: 3 Propuestas sobresalientes para la infraestructura energética."

http://www2.deloitte.com/content/dam/Deloitte/mx/Documents/tax/FinanciamientoEnergetico-FibraE.pdf.

Díaz López, Blanca. 2017. "México Resolverá La Tercera Subasta de Energías Limpias Hasta Octubre." Pv Magazine Latin America. https://www.pv-magazinelatam.com/2017/02/15/mexico-resolvera-la-tercera-subasta-de-energias-limpias-hastaoctubre/.

Doman, Linda, and Laura Singer. 2014. "Energy Reform Could Increase Mexico's Long-Term Oil Production by 75\%." http://www.eia.gov/todayinenergy/detail.cfm?id=17691.

Dyer, Dwight. 2016. "Information Makes or Breaks the Electricity Market." El Daily Post. April 27. http://www.eldailypost.com/opinion/2016/04/information-makes-or-breaks-theelectricity-market/.

El Economista. 2015. "Otorgan primera concesión para planta geotérmica." http://eleconomista.com.mx/industrias/2015/11/03/sener-otorga-primera-concesionplanta-geotermica.

El Financiero. 2016. "Separarán Negocios de CFE En 10 Subsidiarias." http://www.elfinanciero.com.mx/economia/separaran-a-cfe-en-siete-empresas.html. 
ENEL Green Power. 2013. "Geothermal Energy, When Light Emerges from Deep within the Earth." https://www.enelgreenpower.com/en-gb/Documents/plants/geotermia.pdf.

—. 2016. "Power Plants, West \& Midwest US." Accessed August 31. https://www.enelgreenpower.com/ena/en-gb/power_plants/plants/wm.

ESMAP. 2012. "Geothermal Handbook, Planning and Financing Power Generation." https://www.esmap.org/Geothermal_Handbook.

Ex-Im Bank. 2016a. "Environment." http://www.exim.gov/about/special-initiatives/environment. . 2016b. "Key Industries." http://www.exim.gov/learning-resources/key-industries.

_. 2016c. "Renewable Express." http://www.exim.gov/what-we-do/loanguarantee/renewable-express.

EY. 2016. "Energy Alert - Second Long Term Clean Energy Auctions in Mexico." http://www.ey.com/Publication/vwLUAssets/ey-energy-alert-second-clean-energyauctions/\$FILE/ey-energy-alert-second-clean-energy-auctions.pdf.

Flores-Armenta, Magaly. 2013. "Evolución de La Geotermia En El Servicio Público Mexicano." In Foro Internacional Sobre Energía Geotérmica. Mexico City, Mexico.

- 2016. "Mexican Geothermal Activities and the New Electricity Market." https://geothermal.org/Annual_Meeting/PDFs/2016_International/Mexican_Geothermal_ Activities_And_The_New_Electricity_Market.pdf.

Flores-Armenta, Magaly, and Miguel Ramírez-Montes. 2015. "El futuro desarrollo geotérmico de la CFE como nueva empresa productiva.” Michoacán, Mexico. http://geotermia.org.mx/geotermia/Seminario/1-CFE-MFA.pdf.

Gasca Lara, Karla Jessica. 2016. "El sector de energías renovables ante los compromisos del cambio climático.” presented at the Encuentro nacional en respuesta ante el cambio climático, calidad de aire, adaptación y mitigación. http://www.inecc.gob.mx/descargas/difusion/ENRCC/20160628_mitigacion_PE_SENER _K_Gasca.pdf.

Gehringer, Magnus, and Victor Loksha. 2012. "Geothermal Handbook: Planning and Financing Power Generation.” Washington DC: World Bank Group, Energy Sector Management Assistance Program. Accessed November 6, 2013.

GoM. 2013. "Plan Nacional de Desarrollo 2013 - 2018.” http://pnd.gob.mx/wpcontent/uploads/2013/05/PND.pdf.

—. 2014. "Ley de Energía Geotérmica." http:/www.dof.gob.mx/nota_detalle.php?codigo=5355986\&fecha=11/08/2014.

—. 2017. "Recepción, Evaluación Y Resolución Del Informe Preventivo." Gob.mx. http://www.gob.mx/tramites/ficha/recepcion-evaluacion-y-resolucion-del-informepreventivo/SEMARNAT1734.

- n.d. "Reforma Energética."

http://embamex.sre.gob.mx/brasil/images/pdf/Reformas/0211114_reforma_energetica.pdf

Grageda Nunez, Eugenio. 2015. "Mexican Tax Reforms for 2016 | Lexology."

GreenbergTraurig. http:/www.lexology.com/library/detail.aspx?g=c08d8029-b00b4d83-b06d-1437b812d551.

Groenewold, Manuel. 2012. "Sourcing Capital through Mexico's CKD Structure: The Next Phase." http://www.whitecase.com/sites/whitecase/files/files/download/publications/atricleSourcing-Capital-Mexico-CKD.pdf. 
Grupo BMV. n.d. "Fideicomisos de Infraestructura Y Bienes Raíces." https://www.bmv.com.mx/docspub/MI_EMPRESA_EN_BOLSA/CTEN_MINGE/Fibras.pdf.

Gutiérrez Negrín, Luis C.A. 2012. "Update of the Geothermal Electric Potential in México." Geothermal Resources Council Transactions 36: 677. http://pubs.geothermallibrary.org/lib/grc/1030299.pdf.

—. 2015. "Concluye formalmente la ronda cero en geotermia." http://geotermia.org.mx/geotermia/pdf/Resultados-R0.pdf.

— 2016. "Desalentadoras perspectivas para la geotermia." Constructor Eléctrico. June 28. https://constructorelectrico.com/desalentadoras-perspectivas-para-la-geotermia/.

Hiriart Le Bert, Gerardo. 2011. "Evaluación de la Energía Geotérmica en México.” Mexico City, Mexico: Comisión Reguladora de Energía, Banco Interamericano de Desarrollo. http://www.cre.gob.mx/documento/2026.pdf.

IDB. 2014. "CTF - Mexico Geothermal Financing and Risk Transfer Facility." https://www.climateinvestmentfunds.org/cif/sites/climateinvestmentfunds.org/files/Mexic o\%20Geothermal\%20Risk\%20Mitigation\%20Facility\%20-\%20public.pdf.

International Trade Administration. 2011. "The North American Free Trade Agreement (NAFTA)." Export.gov. http://export.gov/fta/nafta/index.asp.

IRENA. 2015a. "Renewable Energy Prospects: Mexico, REmap 2030 Analysis." http://www.irena.org/DocumentDownloads/Publications/IRENA_REmap_Mexico_report 2015.pdf.

_. 2015b. "Renewable Power Generation Costs in 2014." https://www.irena.org/DocumentDownloads/Publications/IRENA_RE_Power_Costs_201 4_report.pdf.

ITA. 2014. "Renewable Energy Top Markets for U.S. Exports 2014-2015, A Market Assessment Tool for U.S. Exporters."

https://build.export.gov/build/groups/public/@eg_main/@reee/documents/webcontent/eg _main_070688.pdf. - 2016a. "2016 Top Markets Report: Renewable Energy." http://www.trade.gov/topmarkets/pdf/Renewable_Energy_Top_Markets_Report.pdf.

—. 2016b. "2016 Top Markets Report, Renewable Energy, Country Case Study." http:/trade.gov/topmarkets/pdf/Renewable_Energy_Mexico.pdf.

—. 2016c. "Mexico - Renewable Energy." Export.gov. https://www.export.gov/article?id=Mexico-Renewable-Energy.

Jiménez, Mariana. 2016. "CFE Legal Restructuring and the Hurdles of Breaking a Monopoly." Renewable Energy Mexico. March 14. http://www.renewableenergymexico.com/cfelegal-restructuring-and-the-hurdles-of-breaking-a-monopoly/.

KPMG. 2016. "Corporate Tax Rates Table." https://home.kpmg.com/xx/en/home/services/tax/tax-tools-and-resources/tax-ratesonline/corporate-tax-rates-table.html.

Lexology. 2015. "Mexico Passes Legislation to Encourage Clean Energy Development." http://www.lexology.com/library/detail.aspx?g=0ea8e838-02b8-4893-b826cc55ea112a8a.

Ley General de Cambio Climático. 2012. http://www.inecc.gob.mx/descargas/2012_lgcc.pdf. López Pineda, Serafín. 2016. The geothermal market in Mexico. 
Martínez, Ana Isabel. 2016. "Española Iberdrola apuesta a casi duplicar generación en México a unos 10,000 megavatios en 2020."

http://mx.reuters.com/article/topNews/idMXL2N18O0VA.

McGovern, Michael. 2016. "Analysis: Mixed Signals from Mexican Auction." http://www.windpowermonthly.com/article/1391268.

MHPS. 2014. "MHPS Receives Full Turnkey Order for Geothermal Power Generation Plant, 13th from Mexico." https://www.mhps.com/en/news/20141029.html.

MIF, DFID, Power Africa, and BNEF. 2015. "Climatescope 2015." http://globalclimatescope.org/en/download/.

MIF, UKaid, Power Africa, and BNEF. 2016. "Latin America \& the Caribbean." Climatescope 2015. http://global-climatescope.org/en/region/lac/.

Miller, Justin S. 2015. "Mexico Sets 2018 Clean Energy Certificate Acquisition Requirement at Five Percent; Related Final Wholesale Power Market Rules Remain Forthcoming." Nexant. http://www.nexant.com/resources/mexico-sets-2018-clean-energy-certificateacquisition-requirement-five-percent-related.

Muñozcano Álvarez, Luis. 2015. "Perspectivas de Desarrollo de la Geotermia en México bajo la Nueva Regulación." http://geotermia.org.mx/geotermia/Seminario/2-SENER.pdf.

Nacional Financiera. 2015. "Crédito Exploratorio Asegurado."

Nieva, D., R.M. Prol-Ledesma, and J.M. Romo-Jones. 2013. "La Geotermia En El Futuro Energético Sustentable de México.” In Foro Internacional Sobre Energía Geotérmica. Mexico City, Mexico.

Ormad, Abraham. 2014. "Entrevista al Grupo Dragón sobre sus actividades en México y perspectivas a nivel internacinoal." Piensa en Geotermia. http://piensageotermia.com/archives/22316.

Ortiz Salgado, Luz Aurora. 2016. "Subastas de Largo Plazo." http://mvdpanel.net/adjuntosTextos/ewxuzcszasq5wr/867/Luz\%20Aurora\%20Ortiz.pptx.

Pavlovic, Jeff. 2015. "Regional Address to the CAISO Stakeholder Symposium: Electricty Reform in Mexico." https://www.caiso.com/Documents/JeffPavlovicPresentationElectricityReformInMexico.pdf.

PV Magazine. 2016. "Marcan Precio Máximo Para Energías Limpias En Subasta En México." http://www.pv-magazine-latam.com/noticias/detalles/articulo/marcan-precio-mximopara-energas-limpias-en-subasta-en-mxico_100021901/.

PV Tech. 2016. "Results of Mexico's US\$4 Billion Second Renewable Energy Auction." https://www.pv-tech.org/news/who-won-what-in-mexicos-us4-billion-second-renewableenergy-auction.

$P w C$. 2014. "Transformación del sector eléctrico mexicano, Implicaciones de la Ley de la Industria Eléctrica y la Ley de la CFE." http://www.pwc.com/mx/es/industrias/archivo/2014-08-transformacion-sector-electricomexicano.pdf.

—. 2015a. "Estudio sobre las inversiones necesarias para que México cumpla con sus metas de Energías Limpias." http://www.cespedes.org.mx/EnergiasLimpias/PwC_CESPEDES_estudio_energias_limpi as.pdf. .2015b. "Reforma fiscal 2016." http://www.pwc.com/mx/es/impuestos/archivo/20151103-pg-foll-reformas-fiscales-2015tls.pdf. 
Quijano-León, José Luis, and Luis C.A. Gutiérrez-Negrín. 2003. “An Unfinished Journey, 30 Years of Geothermal-Electric Generation in Mexico."

http://www.geothermal.org/PDFs/Articles/30yearsmexico.pdf.

Ramírez-Camperos, Adriana María, Víctor Rodríguez-Padilla, and Pedro Antonio Guido-Aldana. 2013. "The Mexican Electricity Sector: Policy Analysis and Reform (1992-2009)." Energy Policy 62 (November): 1092-1103. doi:10.1016/j.enpol.2013.06.063.

Rhazi, Nadia. 2016. "Overseas Private Investment Corporation."

Richter, Alexander. 2009. "Mexican CFE's Bidding Process to Add $100 \mathrm{MW}$ to Cerro Prieto Plant." Think GeoEnergy - Geothermal Energy News.

http://www.thinkgeoenergy.com/mexican-cfes-bidding-process-to-add-100-mw-to-cerroprieto-plant/.

—. 2012a. "Alstom Signs \$38m Turnkey Contract with CFE for Los Humeros II Phase B Plant." Think GeoEnergy - Geothermal Energy News. http://www.thinkgeoenergy.com/alstom-signs-38m-turnkey-contract-with-cfe-for-loshumeros-ii-phase-b-plant/.

- 2012b. "Four Companies Bidding for Geothermal EPC Contract at Los Azufres, Mexico." Think GeoEnergy - Geothermal Energy News. http://www.thinkgeoenergy.com/four-companies-bidding-for-geothermal-epc-contract-atlos-azufres-mexico/.

. 2012c. "Mitsubishi HI Receives Full Turnkey Order for 50 MW Los Azufres III." Think GeoEnergy - Geothermal Energy News. http://new.thinkgeoenergy.com/mitsubishiheavy-industries-receives-full-turnkey-order-for-50-mw-los-azufres-iii/.

—. 2014a. "Mexico to Develop Exploration Risk Mitigation Program for IPP Projects." Think GeoEnergy - Geothermal Energy News. http://www.thinkgeoenergy.com/mexicoto-develop-exploration-risk-mitigation-program-for-ipp-projects/.

—. 2014b. "Mitsubishi Hitachi Wins 25 MW Plant Contract in Mexico." Think GeoEnergy - Geothermal Energy News. http://www.thinkgeoenergy.com/mitsubishi-hitachi-wins-25mw-plant-contract-in-mexico/.

—. 2016a. "CFE Geothermal Project Successful in Mexico's 2nd Renewable Energy Auction.” Think GeoEnergy - Geothermal Energy News. http://www.thinkgeoenergy.com/cfe-geothermal-project-successful-in-mexicos-2ndrenewable-energy-auction/.

- 2016b. "Will 2016 Be the Year of Geothermal Energy in Mexico?" Think GeoEnergy Geothermal Energy News. http://www.thinkgeoenergy.com/will-2016-be-the-year-ofgeothermal-energy-in-mexico/.

Rojas, Francisco. 2014. "CFE Plans Partnerships with Foreign Firms for Geothermal Development in Mexico." Think GeoEnergy - Geothermal Energy News. http://www.thinkgeoenergy.com/cfe-plans-partnerships-with-foreign-firms-forgeothermal-development-in-mexico/.

- 2015. "Mexican Geothermal Association Held Successful 22nd Annual Congress and Assembly." Think GeoEnergy - Geothermal Energy News. http://www.thinkgeoenergy.com/mexican-geothermal-association-held-successful-22ndannual-congress-and-assembly/. 
Rosellón, Juan, and Jonathan Halpern. 1999. Regulatory Reform in Mexico's Natural Gas Industry: Liberalization in the Context of a Dominant Upstream Incumbent. Policy Research Working Papers. The World Bank. http://elibrary.worldbank.org/doi/book/10.1596/1813-9450-2537.

Sanyal, Subir K., Ann Roberson-Tait, Migara S. Jayawardena, Gerry Huttrer, and Laura Berman. 2016. "Comparative Analysis of Approaches to Geothermal Resource Risk Mitigation: A Global Survey." ESMAP. http://documents.worldbank.org/curated/en/621131468180534369/pdf/105172-ESMP144569-PUBLIC-FINAL-ESMAP-GeoRiskMitigation-KS024-16-web.pdf.

SEGOB. 2016a. "TÉRMINOS Para La Asignación de Activos Y Contratos Para La Generación a Las Empresas Productivas Subsidiarias Y Empresas Filiales de La Comisión Federal de Electricidad." http://www.dof.gob.mx/nota_detalle.php?codigo $=5459866 \&$ fecha $=04 / 11 / 2016$.

_. 2016b. "TÉRMINOS para la estricta separación legal de la Comisión Federal de Electricidad." Diario Oficial de la Federación. http://www.dof.gob.mx/nota_detalle.php?codigo=5422390\&fecha=11/01/2016.

SENER. 2012a. "Iniciativa para el Desarrollo de las Energías Renovables en México." http://www.pwc.com/mx/es/industrias/infraestructura/archivo/2013-06-iniciativarenovable-sener-geotermia.pdf.

. 2012b. "Prospectiva del sector electrico 2012-2026." Mexico: Secretaría de Energía. http://www.gob.mx/cms/uploads/attachment/file/62958/Prospectiva_del_Sector_El_ctric o_2012-2026.pdf.

. 2015. "Prospectiva del Sector Eléctrico 2015-2029."

https://www.gob.mx/cms/uploads/attachment/file/44328/Prospectiva_del_Sector_Electric o.pdf.

. 2016a. "Avanza el proceso de separación de la CFE y su grupo corporativo." gob.mx. http://www.gob.mx/sener/prensa/avanza-el-proceso-de-separacion-de-la-cfe-y-su-grupocorporativo.

_. 2016b. "Boletín de Energías Limpias" 2 (16). http://www.gob.mx/cms/uploads/attachment/file/151031/Bolet_n_ENERG_AS_LIMPIA S_dieciseis.pdf.

. 2016c. "Inventario Nacional de Energías Renovables." http://inere.energia.gob.mx/. . 2016d. "Inversión de 4 mil millones de dólares al concluir el proceso de la Segunda Subasta Eléctrica." gob.mx. http://www.gob.mx/sener/prensa/inversion-de-4-milmillones-de-dolares-al-concluir-el-proceso-de-la-segunda-subasta-electrica69919? idiom=es. . 2016e. "Nutrida Participación En La Fase Inicial de La Primera Subasta de Largo Plazo Del Mercado Eléctrico." Gob.mx. http://www.gob.mx/sener/prensa/nutrida-participacionen-la-fase-inicial-de-la-primera-subasta-de-largo-plazo-del-mercado-electrico.

— . 2016f. "Programa de Desarrollo del Sistema Eléctrico Nacional 2016 - 2030 (PRODESEN)." https://www.gob.mx/sener/acciones-y-programas/programa-dedesarrollo-del-sistema-electrico-nacional-33462?idiom=es. . 2016g. "Prospectiva Del Sector Eléctrico 2016-2030." http://www.gob.mx/cms/uploads/attachment/file/177626/Prospectiva_del_Sector_El_ctri co_2016-2030.pdf.

. 2016h. "Sistema de Información Energética." http://sie.energia.gob.mx/. 
Sener, Adil Caner, J. R. V. Dorp, and Jesse Dylan Keith. 2009. "Perspectives on the Economics of Geothermal Power." GRC Trans 33: 29-36. http://www.seas.gwu.edu/ dorpjr/Publications/ConferenceProceedings/GRC2009.pdf.

Sternthal, Rob. 2016. "Opportunities Dawning For U.S. Renewable Energy Companies In Mexico." http://www.forbes.com/sites/energysource/2016/01/20/opportunities-dawningfor-u-s-renewable-energy-companies-in-mexico/\#58715d5f5cba.

Trabish, Herman K. 2013. "A Whole New Way of Thinking About Geothermal: Greentech Media.” June 27. http://www.greentechmedia.com/articles/read/a-whole-new-way-ofthinking-about-geothermall.

Tron, Manuel E, and Federico Scheffler. 2016. "Expert Guides - Reconsidering the Figure of FICAP as a Vehicle for Private Equity Investments in Mexico." Expert Guides. http://www.expertguides.com:8080/articles/reconsidering-the-figure-of-ficap-as-avehicle-for-private-equity-investments-in-mexico/arjevkdm.

U.S. Census Bureau. 2016. "Foreign Trade: US Top Trading Partners." http://www.census.gov/foreign-trade/statistics/highlights/top/top1512yr.html.

U.S. TDA. 2016. "FY 2017 Congressional Budget Justification." https://www.ustda.gov/sites/default/files/pdf/about/reports/FY2017_CongressionalBudget Justification.pdf.

_. 2017. "Our Mission." https://www.ustda.gov/about/mission.

World Bank. 2016. "Ranking of Economies - Doing Business." http://www.doingbusiness.org/rankings. 


\section{Appendix A - Contacts in Key Organizations}

\begin{tabular}{|c|c|c|c|c|}
\hline Organization & Name & Position & Phone \# & Email \\
\hline Nafinsa - Development bank & Gabriela Larenas Ruiz & $\begin{array}{l}\text { Director of } \\
\text { Sustainability Projects }\end{array}$ & $\begin{array}{l}+52(55) 5325- \\
6365\end{array}$ & gilarenas@nafin.gob.mx \\
\hline SENER - Ministry of Energy & Michelle Ramírez & $\begin{array}{l}\text { Director of Geothermal } \\
\text { Energy }\end{array}$ & $\begin{array}{l}+52(55) 5000- \\
6000, \text { ext. } 1072\end{array}$ & maramirez@energia.gob.mx \\
\hline Mexican Geothermal Association & $\begin{array}{l}\text { Georgina Izquierdo } \\
\text { Montalvo }\end{array}$ & President & $\begin{array}{l}+52(777) 362- \\
3811, \text { ext. } 7321\end{array}$ & gim@iie.org.mx \\
\hline $\begin{array}{l}\text { CEMIE Geo - Geothermal } \\
\text { Research Center }\end{array}$ & José Manuel Romo Jones & Technical Director & $\begin{array}{l}+52(646) \\
1750500\end{array}$ & jromo@cicese.mx \\
\hline $\begin{array}{l}\text { CONAGUA - National Water } \\
\text { Commission }\end{array}$ & Rubén Chávez & $\begin{array}{l}\text { Groundwater } \\
\text { department manager }\end{array}$ & $\begin{array}{l}+52(55) 5174- \\
4422\end{array}$ & ruben.chavez@conagua.gob.mx \\
\hline $\begin{array}{l}\text { ProMexico - Government } \\
\text { organization to promote trade and } \\
\text { investment }\end{array}$ & Erika Salazar Sugich & $\begin{array}{l}\text { Energy and } \\
\text { Environmental } \\
\text { Technologies } \\
\text { Coordinator }\end{array}$ & $\begin{array}{l}+52(55) 5447- \\
7000, \text { ext. } 1240\end{array}$ & erika.salazar@promexico.gob.mx \\
\hline $\begin{array}{l}\text { CRE - Energy Regulatory } \\
\text { Commission }\end{array}$ & $\begin{array}{l}\text { Eduardo René Narváez } \\
\text { Torres }\end{array}$ & $\begin{array}{l}\text { Clean Energy } \\
\text { Regulation Director }\end{array}$ & $\begin{array}{l}+52(55) 5283- \\
1500\end{array}$ & enarvaez@cre.gob.mx \\
\hline $\begin{array}{l}\text { CENACE - National Center for } \\
\text { Energy Control }\end{array}$ & Help Desk & & $\begin{array}{l}+52(55) 5724- \\
5860\end{array}$ & \\
\hline U.S. Embassy in Mexico & Claudia Salgado & Commercial Specialist & $\begin{array}{l}+52(55) 4450- \\
0472\end{array}$ & Claudia.Salgado@trade.gov \\
\hline Export Import Bank & Craig O'Connor & $\begin{array}{l}\text { Director, Office of } \\
\text { Renewable Energy \& } \\
\text { Environmental Exports }\end{array}$ & (202) 565-3556 & craig.oconnor@exim.gov \\
\hline $\begin{array}{l}\text { Overseas Private Investment } \\
\text { Corporation }\end{array}$ & Nadia Rhazi & $\begin{array}{l}\text { Global Energy Group } \\
\text { Program Manager }\end{array}$ & (202) 357-3912 & Nadia.Rhazi@opic.gov \\
\hline $\begin{array}{l}\text { U.S. Trade and Development } \\
\text { Agency }\end{array}$ & Kendra Link & $\begin{array}{l}\text { Senior Advisor for } \\
\text { Policy and Operations }\end{array}$ & & klink@ustda.gov \\
\hline U.S. Commercial Service & Jeffrey Justice & Commercial Attaché & $\begin{array}{l}+52(55) 5080 \\
2195\end{array}$ & Jeffrey.Justice@trade.gov \\
\hline
\end{tabular}




\begin{tabular}{|c|c|c|c|c|}
\hline Organization & Name & Position & Phone \# & Email \\
\hline USAID Mexico City & Donald McCubbin & Environment Officer & $\begin{array}{l}+521(55) 4447 \\
9295\end{array}$ & dmccubbin@usaid.gov \\
\hline $\begin{array}{l}\text { Inter-American Development } \\
\text { Bank }\end{array}$ & Enrique Nieto & $\begin{array}{l}\text { Financial Markets } \\
\text { Lead Specialist }\end{array}$ & (202) 623-2340 & enriquen@iadb.org \\
\hline International Trade Administration & Patrick Krissek & $\begin{array}{l}\text { International Trade } \\
\text { Specialist }\end{array}$ & (202) 482-4231 & Patrick.Krissek@trade.gov \\
\hline International Trade Administration & Cora Dickson & $\begin{array}{l}\text { Senior International } \\
\text { Trade Specialist }\end{array}$ & (202) 482-6083 & Cora.Dickson@trade.gov \\
\hline Geothermal Energy Association & Rani Chatrath & $\begin{array}{l}\text { Global Initiatives } \\
\text { Coordinator }\end{array}$ & (202) 454-5261 & Rani@geo-energy.org \\
\hline $\begin{array}{l}\text { Office of Energy Efficiency and } \\
\text { Renewable Energy at DOE }\end{array}$ & Andrew Graves & $\begin{array}{l}\text { Policy Advisor, } \\
\text { International Program }\end{array}$ & (202) 586-1071 & andrew.graves@ee.doe.gov \\
\hline $\begin{array}{l}\text { National Renewable Energy } \\
\text { Laboratory }\end{array}$ & Francisco Flores-Espino & $\begin{array}{l}\text { Energy Analyst, } \\
\text { Strategic Energy } \\
\text { Analysis Center }\end{array}$ & (303) 384-7385 & francisco.flores@nrel.gov \\
\hline
\end{tabular}




\section{Appendix B - Registration, Permit, and License Minimum Requirements}

Registration applications for geothermal survey activities require the following minimum information. ${ }^{17}$ SENER may require more information at their discretion.

- Applicant's information, including name, address, tax identification number, legal representative, and geothermal activity area

- Registration payment receipt

- Geospatial information describing the area to be surveyed

- Documentation showing surface rights

- Legal standing/capacity

○ Personal identification form (for individuals), incorporation documentation (for companies) showing that geothermal activities permitted under their charter

- Technical capacity

○ List of geothermal activities performed in the previous five years, including project names and countries

○ Personnel resumes showing their capabilities to perform geothermal activities

- Financial capacity

○ Financial statements for the previous two years

For exploration permits:

- All of the information required for geothermal registration

- Geothermal registry information

- SEMARNAT authorization

- Geothermal activity timeline including:

- Number of planned geothermal wells

○ Financing plan including cash flow projections and sources of financing

For licenses:

- All of the information required for geothermal exploration

- SEMARNAT authorization

- Exploration phase report

- Water license

\footnotetext{
${ }^{17}$ Mexican Geothermal Regulations: http://dof.gob.mx/nota_detalle.php?codigo=5366670\&fecha=31/10/2014
} 


\section{Appendix C - The Electricity System in Mexico}

\section{Current Transmission Infrastructure}

Mexico's transmission infrastructure is comprised of a single, interconnected system throughout the country, except for the isolated transmission systems of the northwestern states of Baja California and Baja California Sur. Mexico's transmission grid has several points of interconnection with the United States, Guatemala, and Belize (Figure 10). Eleven interconnections with a combined transmission capacity of 1,913 MW connect the National Electric System with the electric systems of CAISO, Electric Reliability Council of Texas (ERCOT), and El Paso Electric Company (EPE).

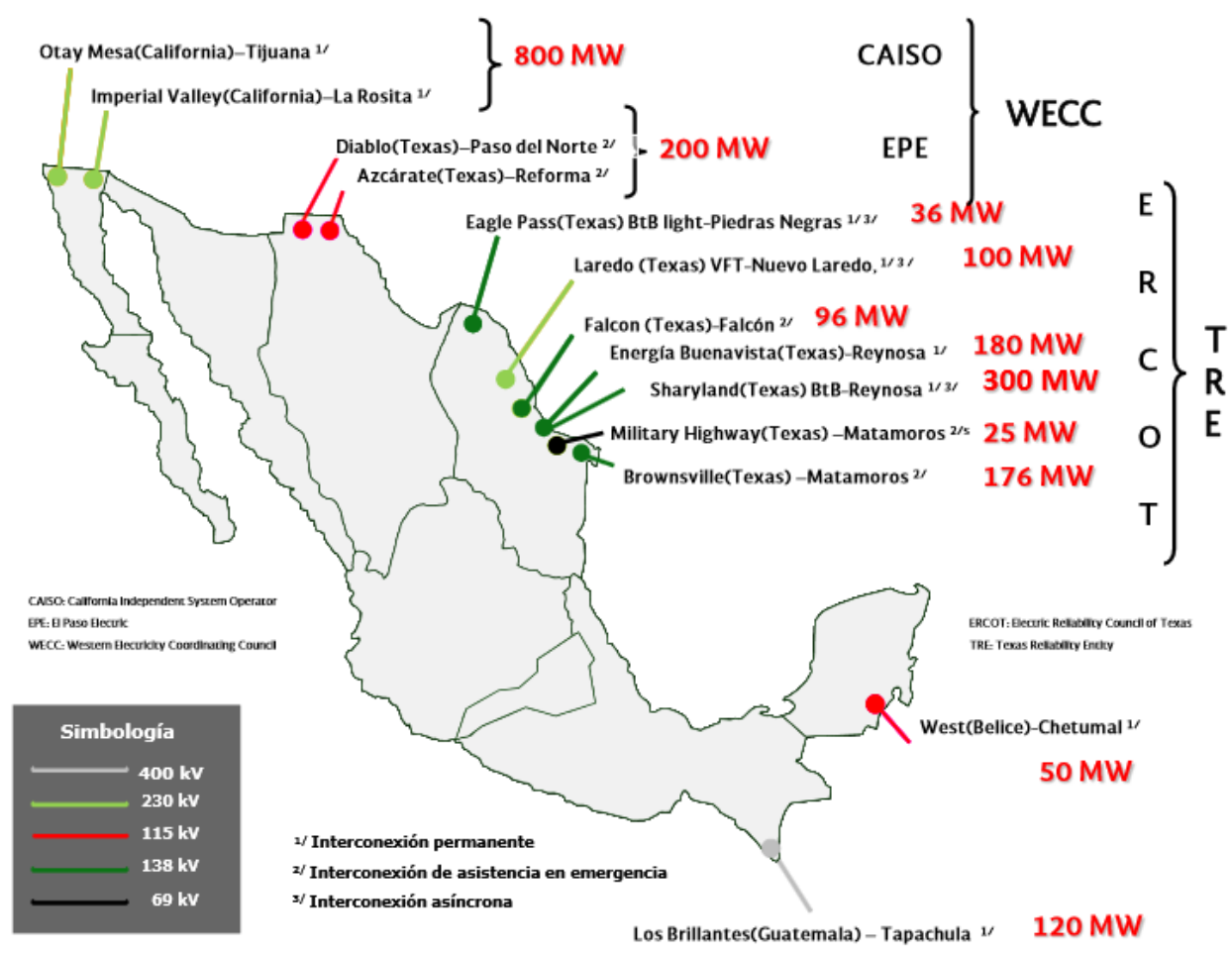

Figure 10. Mexico's international interconnections, 2014 (SENER 2015)

In 2014, the country imported 2,124 gigawatt-hours (GWh) and exported 2,653 GWh to and from the United States, Belize, and Guatemala. Over the past 10 years, electricity has been traded both ways, but generally Mexico has exported more power to the United States, than it has imported - except most recently in 2012, when imports from the United States more than tripled, causing the trade balance to be negative for the first time since 2002 (Figure 11) (SENER 2012b; SENER 2015). 


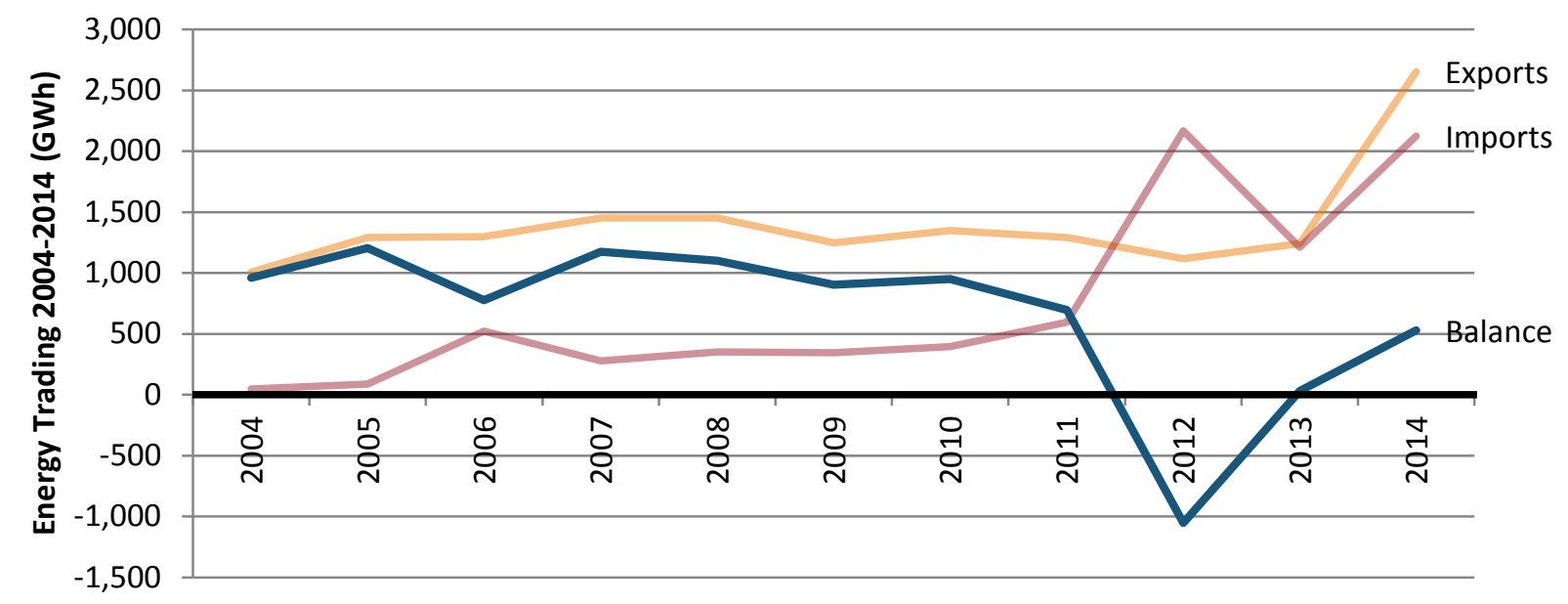

Figure 11. Mexico's annual electricity trade (SENER 2015)

\section{Fuel and Technology Mix}

Mexico had 68 gigawatts (GW) of installed capacity by the end of 2015 (SENER 2016g). The electricity generation fuel mix in Mexico is dominated by fossil fuels. In 2015, fossil fuels were used to generate $80 \%$ of electricity (Table 4). Renewables, including hydroelectric, were used to generate $15 \%$ of total electricity, with hydroelectric generation representing $12 \%$. The peak electricity demand in Mexico is expected to grow 3.5\% per year (SENER 2016g).

Table 4. Fuel Sources Used for Electricity Generation in Mexico in 2015 (SENER 2016g)

\begin{tabular}{|l|l|l|}
\hline Fuel/Technology & $\begin{array}{l}\text { Generation } \\
\text { (TWh) }\end{array}$ & Percentage \\
\hline Fossil & & \\
\hline Natural gas & 151.5 & $58 \%$ \\
\hline Coal & 33.5 & $13 \%$ \\
\hline Fuel oil & 24.1 & $9 \%$ \\
\hline Diesel & 1.4 & $1 \%$ \\
\hline Non-fossil & & \\
\hline Hydro & 30.1 & $12 \%$ \\
\hline Nuclear & 11.6 & $4 \%$ \\
\hline Geothermal & 6.3 & $2 \%$ \\
\hline Wind & 2.4 & $1 \%$ \\
\hline Solar PV & 0 & $0 \%$ \\
\hline Total & 260.8 & $100 \%$ \\
\hline
\end{tabular}

